\title{
Extracellular matrix of the central nervous system: from neglect to challenge
}

\author{
Dieter R. Zimmermann • María T. Dours-Zimmermann
}

Accepted: 26 July 2008 / Published online: 12 August 2008

(C) Springer-Verlag 2008

\begin{abstract}
The basic concept, that specialized extracellular matrices rich in hyaluronan, chondroitin sulfate proteoglycans (aggrecan, versican, neurocan, brevican, phosphacan), link proteins and tenascins (Tn-R, Tn-C) can regulate cellular migration and axonal growth and thus, actively participate in the development and maturation of the nervous system, has in recent years gained rapidly expanding experimental support. The swift assembly and remodeling of these matrices have been associated with axonal guidance functions in the periphery and with the structural stabilization of myelinated fiber tracts and synaptic contacts in the maturating central nervous system. Particular interest has been focused on the putative role of chondroitin sulfate proteoglycans in suppressing central nervous system regeneration after lesions. The axon growth inhibitory properties of several of these chondroitin sulfate proteoglycans in vitro, and the partial recovery of structural plasticity in lesioned animals treated with chondroitin sulfate degrading enzymes in vivo have significantly contributed to the increased awareness of this long time neglected structure.
\end{abstract}

Keywords CSPG $\cdot$ Lectican $\cdot$ Hyalectan $\cdot$ ADAMTS . Hyaluronan synthase · Perineuronal net · Node of Ranvier . Knockout $\cdot$ Tenascin $\cdot$ Link protein $\cdot$ Central nervous system

\section{Introduction}

It was not until 1971 that the existence of an extracellular matrix (ECM) in the central nervous system (CNS) was generally acknowledged (Tani and Ametani 1971). Then a predominance of hyaluronan and chondroitin sulfate proteoglycans (CSPG) (Margolis et al. 1975) and the paucity of otherwise frequent ECM molecules, like fibronectin or collagens, have been described (Carbonetto 1984; Rutka et al. 1988; Sanes 1989). Today we know that this distinctive ECM is mainly composed of proteoglycans of the lectican/ hyalectan-family and their binding partners, hyaluronan, link proteins and tenascins (Bandtlow and Zimmermann 2000; Novak and Kaye 2000; Rauch 1997, 2004; Ruoslahti 1996; Yamaguchi 2000). In the following, we will focus on the structure, expression and putative functions of this major matrix components that form this extraordinary extracellular meshwork. Not discussed in this review are less abundant, but nonetheless functionally important macromolecules of the nervous system, such as reelin, agrin and thrombospondins. For detailed information about these large glycoproteins, which are involved in the control of neuronal migration and establishment of synapses we would like to refer the reader to recent reviews and publications (Bezakova and Ruegg 2003; Christopherson et al. 2005; Herz and Chen 2006; Tissir and Goffinet 2003).

\section{Structures and ligands of the major constituents of the neural ECM}

Proteoglycans and hyaluronan

Proteoglycans (PGs) are glycoproteins carrying, in addition to variable numbers of $\mathrm{N}$ - and $\mathrm{O}$-linked oligosaccharides, at
D. R. Zimmermann $(\bowtie) \cdot$ M. T. Dours-Zimmermann Division of Diagnostic Molecular Pathology, Institute of Surgical Pathology, University Hospital Zurich, Schmelzbergstrasse 12, 8091 Zurich, Switzerland e-mail: dieterzi@pathol.uzh.ch; dieter.zimmermann@usz.ch 
least one glycosaminoglycan (GAG) side chain, which is covalently bound to a core protein. The GAGs themselves are long unbranched polymers of repetitive disaccharide units consisting of an uronic acid (glucuronic or iduronic) or galactose and an amino-sugar ( $\mathrm{N}$-acetylglucosamine or $\mathrm{N}$-acetylgalactosamine). According to the combination of these sugars, the GAGs are subclassified into heparin/heparan-, keratan- or chondroitin/dermatan-sulfates (Bandtlow and Zimmermann 2000; Kjellén and Lindahl 1991; Prydz and Dalen 2000). The GAG chains are in general 20-200 disaccharide-repeats long. Whereas keratan sulfates are usually attached to the core proteins via short standard Nor O-glycan links to asparagine or serine/threonine, respectively, the binding of chondroitin/dermatan sulfate and of heparin/heparan sulfate chains is mediated by a serine residue and a specific linker tetrasaccharide composed of a xylose, two consecutive galactoses and a glucuronic acid molecule. Numerous modifications that include $\mathrm{O}-$ and $\mathrm{N}$ sulfation and epimerization of glucuronic acid at the C5position lead to a high structural variability and open up countless possibilities for the modulation of GAG-dependent interactions (Bulow and Hobert 2006; Kusche-Gullberg and Kjellen 2003). Moreover, the highly negatively charged GAGs attract and bind considerable amount of water and cations.

In contrast to the protein-bound GAGs, hyaluronan (also known as hyaluronic acid or hyaluronate) is incorporated into the extracellular matrix as a core protein-free glycosaminoglycan (Toole 2000, 2004). Hyaluronan is a very large linear polymer built of repetitive disaccharides units consisting of glucuronic acid and $\mathrm{N}$-acetylglucosamine. This carbohydrate filament reaches a molecular mass of up to $10^{7} \mathrm{Da}$ and extends over lengths of 2-25 $\mu \mathrm{m}$. Unlike the other GAGs, hyaluronan is not sulfated and the glucuronic acid units are not epimerized.

While the more complex core protein-bound GAGs are assembled and modified by a large set of glycosyl- and sulfotransferases, the structurally simpler hyaluronan is synthesized by a single enzyme, the hyaluronan synthase (HAS). Three vertebrate genes (HAS1, HAS2, and HAS3) giving rise to three HAS isoenzymes have been identified (DeAngelis 1999; Itano and Kimata 2002; Spicer and McDonald 1998; Weigel et al. 1997). The HAS are rather unique, as they catalyze the incorporation of two different monosaccharides and are, in contrast to most other glycosyltransferases, localized at the inner surface of the cell membrane. From there the growing hyaluronan string directly extrudes into the pericellular space, while being still attached to the producing enzyme (Spicer and Tien 2004; Weigel et al. 1997).

The most prominent binding partners of hyaluronan in the nervous system are the extracellular matrix proteoglycans of the lectican family (also called hyalectans) (reviewed by Bandtlow and Zimmermann 2000; Iozzo and Murdoch 1996; Rauch 2004; Ruoslahti 1996; Yamaguchi 2000). In mammals, four distinct lectican genes encode brevican, neurocan, aggrecan and versican (Table 1; Fig. 1). Shared features among these large chondroitin sulfate proteoglycans are the highly homologous G1 and G3 domains, which appear in rotary shadowing electron microscopy as compact globular structures at either end of an extended, but flexible central region (Mörgelin et al. 1989; Retzler et al. 1996). This poorly sequence-conserved middle part carries most of the $\mathrm{O}$ - and $\mathrm{N}$-linked oligosaccharides and all glycosaminoglycan side chains. It varies among the different family members in size and also in the number of carbohydrate substitutions. Occasionally, the GAGs might even be absent, like in a fraction of the parttime preoteoglycan brevican, or they may be greatly diminished, as in CNS-derived aggrecan in relation to its cartilage counterpart. Apart from the variations within the carbohydrate moiety, alternative splicing also greatly adds to the structural diversity of lecticans. Four versican isoforms (V0, V1, V2 and V3) exist as a result of alternative usage of two giant exons encoding the central GAG- $\alpha$ and GAG- $\beta$ domains (Dours-Zimmermann and Zimmermann 1994; Zako et al. 1995; Zimmermann and Ruoslahti 1989). Versican V0 contains both of these GAG-attachment modules, whereas versican V1 and V2 include only the GAG- $\beta$ or GAG- $\alpha$, respectively. Versican V3, the smallest lectican,
Table 1 Extracellular matrix CSPGs in the central nervous system

\footnotetext{
${ }^{\mathrm{a}} \mathrm{kDa}$

b Mature polypeptide

c Core glycoprotein after glycosaminoglycan removal

${ }^{\mathrm{d}}$ Minor expression in peripheral nervous system
}

\begin{tabular}{|c|c|c|c|c|c|c|}
\hline \multirow[t]{2}{*}{ Name } & \multicolumn{2}{|l|}{ Core size $^{\mathrm{a}}$} & \multicolumn{2}{|l|}{ GAGs } & \multirow[t]{2}{*}{ Cellular origin } & \multirow{2}{*}{$\begin{array}{l}\text { CNS- } \\
\text { specific }\end{array}$} \\
\hline & Calculated $^{\mathrm{b}}$ & SDS-PAGE & Type & Number & & \\
\hline Aggrecan & 244 & 370 & $\mathrm{CS}$ & $?$ & Neurons/astrocytes & No \\
\hline Versican V0 & 371 & $\approx 550$ & $\mathrm{CS}$ & $17-23$ & Neurons/astrocytes? & No \\
\hline Versican V1 & 263 & $\approx 500$ & $\mathrm{CS}$ & $12-15$ & Astrocytes? & No \\
\hline Versican V2 & 180 & 400 & $\mathrm{CS}$ & $5-8$ & Oligodendroglial lineage & Yes \\
\hline Neurocan & 141 & 245 & $\mathrm{CS}$ & 3 & Astrocytes/neurons & Yes $^{\mathrm{d}}$ \\
\hline Brevican & 97 & 145 & $\mathrm{CS}$ & $0-5$ & Glial cells/neurons & Yes \\
\hline $\begin{array}{l}\text { Phosphacan } \\
\text { (-KS) }\end{array}$ & 172 & 400 & $\mathrm{CS} /(\mathrm{KS})$ & $3-4$ & Glial cells/neurons & Yes \\
\hline
\end{tabular}




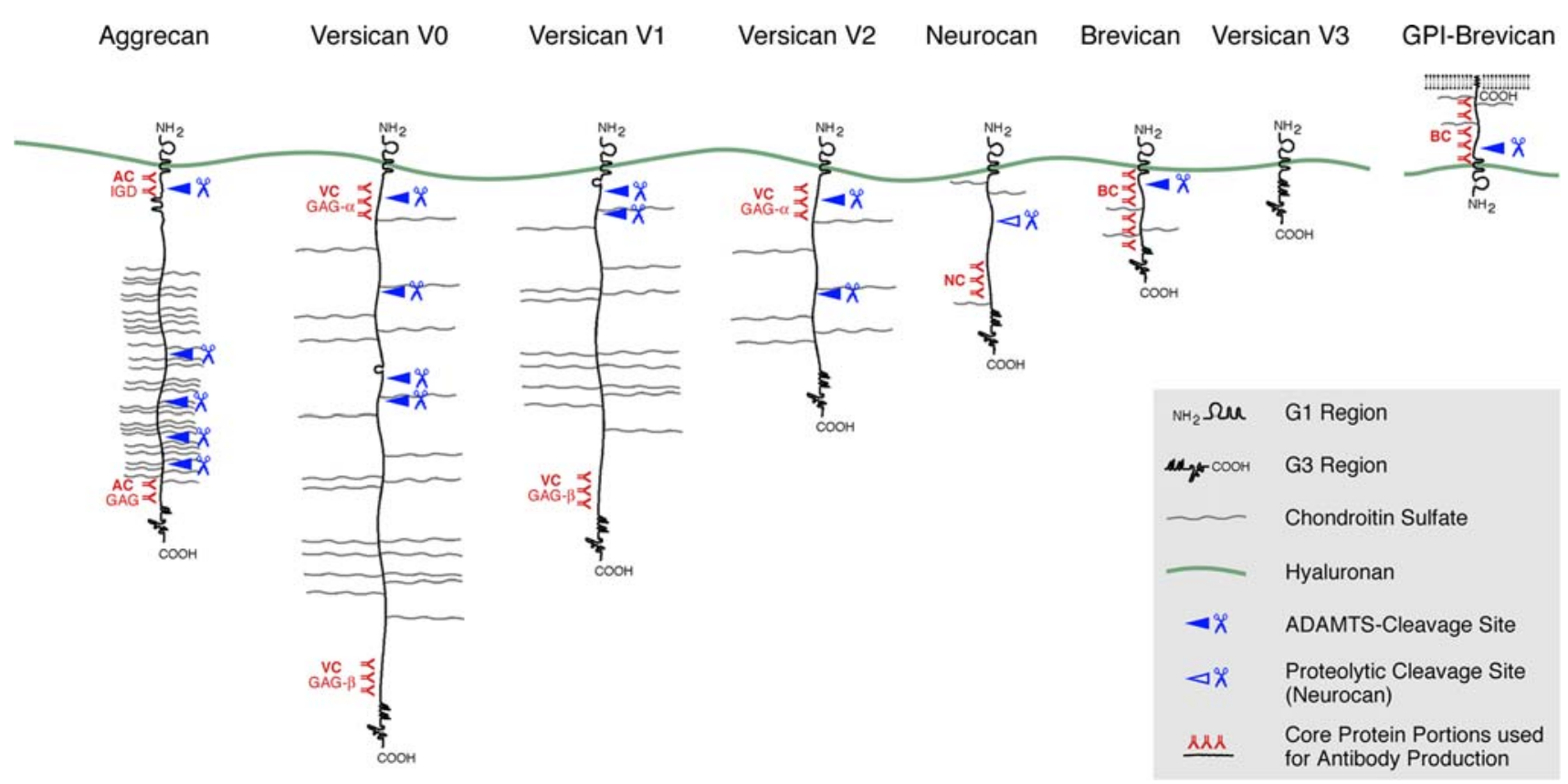

Fig. 1 Structural models of the chondroitin sulfate proteoglycans of the lectican family. ADAMTS cleavage sites and binding regions of the polyclonal antibodies used in immunohistochemical stainings displayed in the following figures are indicated

lacks both of these alternatively spliced elements and consequently carries no glycosaminoglycans.

In contrast to these largely diversified GAG-binding regions, the modules that form the globular G1 and G3 structures display little variability. For instance, all N-terminal G1 regions of the different lecticans include an immunoglobulin (Ig)-like loop and two link-protein-like tandem repeats that are involved in the binding of hyaluronan and link proteins (LeBaron et al. 1992; Mörgelin et al. 1989; Neame et al. 1987; Rauch et al. 2004). The G3 globule at the other end of the core protein contains a C-type lectin-like element, which is flanked by one or two EGFrepeats and a Sushi $(\mathrm{SCR} / \mathrm{CCP})$ domain, respectively. The entire G3 region is only absent in a GPI-anchored brevicanvariant arising from alternative transcription termination (Seidenbecher et al. 1995). Recombinantly expressed G3 domains and/or the C-type lectin elements alone bind in vitro simple carbohydrates and heparin or heparan sulfate (Ujita et al. 1994), fibulin-1 and -2 (Aspberg et al. 1999; Olin et al. 2001), fibrillin-1 (Isogai et al. 2002), sulfoglycolipids (Miura et al. 1999) and the tenascins, Tn-C and Tn-R (Aspberg et al. 1995, 1997; Day and Prestwich 2002; Rauch et al. 1997). Of note, the majority of the G1- and G3ligands are recognized by all lecticans, albeit differences in the affinities exist. Completing the structural models of the lecticans and their splice-variants by including the singular GAG-attachment regions between the largely homologous globular ends makes evident that this proteoglycan family forms an almost perfect array of functionally closely related but differently sized modular proteins (Fig. 1).
Besides the large aggregating proteoglycans of the lectican family, phosphacan, a secreted CSPG-isoform of the receptor-type protein-tyrosine phosphatase $\beta(\operatorname{RPTP} \beta)$, plays a prominent role in the brain ECM (Barnea et al. 1994; Maurel et al. 1994; Shitara et al. 1994). Like the other alternative splice products of the RPTP $\beta$ gene, it is composed of a carbonic anhydrase domain, a fibronectin type III repeat and a spacer element, but lacks the transmembrane domain and the cytoplasmic tyrosine phosphatase modules. An additional element, present in phosphacan and the larger phosphatase variant, carries three to four chondroitin sulfate chains and sporadically also a few keratan sulfates (Rauch et al. 1991).

Phosphacan/RPTP $\beta$ binds in a calcium-dependent manner to the ECM glycoproteins tenascin-R and tenascin-C (Milev et al. 1997; Xiao et al. 1997). It furthermore interacts in vitro with various cell adhesion molecules of the Ig-superfamily (IgCAMs) including N-CAM, Ng-CAM, axonin-1 (TAG-1) and contactin (F3/F11) (Milev et al. 1994, 1996; Peles et al. 1995), and it binds to the extracellular portion of voltage-gated sodium channels (Ratcliffe et al. 2000). The interaction with contactin and the sodium channels seems to be mediated by the carbonic anhydrase (CAH) domain of RPTP $\beta /$ phosphacan (Peles et al. 1995; Ratcliffe et al. 2000).

Link proteins

The interaction between hyaluronan and lecticans is reinforced by small link proteins, collectively denominated 
HAPLNs (hyaluronan and proteoglycan binding link proteins) (Spicer et al. 2003). This family of ancillary glycoproteins consists of four members, including the classical cartilage link protein $($ HAPLN1 $=$ Crt11) $($ Neame and Barry 1993). Since its discovery several decades ago, HAPLN1 Crtl1 has also been detected in brain, where it joins two other link proteins, the CNS-restricted HAPLN2/Brall and HPLN4/Bral2 (Bekku et al. 2003; Hirakawa et al. 2000). Only HAPLN3/Lp3 seems to be absent from the brain parenchyma, however, being expressed by the smooth muscle cells of larger blood vessels (Ogawa et al. 2004; Spicer et al. 2003).

The structure of the link proteins strongly resembles the globular G1 regions of lecticans, as they are all built-up of an Ig-fold and a hyaluronan-binding tandem repeat. There is some evidence that the interaction with lecticans may either be mediated by the Ig-fold (aggrecan) or by the tandem repeat of the link protein (versican). This functional relationship between HAPLNs and lecticans is also reflected in their chromosomal location and genomic organization. Intriguingly, each of the link protein genes is paired up with one of the lectican genes: HAPLN1 with VCAN, HAPLN2 with BCAN, HAPLN3 with AGC and HAPLN4 with NCAN (Spicer et al. 2003). Despite this particularity, the expression and binding preferences of link proteins and lecticans seem to be uncoupled from their genomic setup. For instance, HAPLN1/Crt11 is co-expressed and interacts with aggrecan in cartilage and possibly in brain, while versican, V0 and V1, and HAPLN3/Lp3 are both synthesized in smooth muscle tissues and may bind to each other at these locations (Ogawa et al. 2004). Alternatively, the same versican isoforms or neurocan may team up with HAPLN1/ Crtl1 to form ternary complexes with hyaluronan during brain development (Hirakawa et al. 2000; Matsumoto et al. 2003; Rauch et al. 2004; Seyfried et al. 2005; Shi et al. 2004). Finally, there are strong indications that pairs of HAPLN2/Bral1 and versican V2 (Oohashi et al. 2002) and of HAPLN4/Bral2 and brevican associate in mature brain tissues with hyaluronan (Bekku et al. 2003).

\section{Tenascins}

Apart from hyaluronan, lecticans and link proteins, tenascins represent the fourth class of molecules that form the basic constituents of the brain ECM. Tenascins (Tn) are very large multimeric glycoproteins that are well conserved among vertebrates (reviewed by Chiquet-Ehrismann and Chiquet 2003; Hsia and Schwarzbauer 2005; Joester and Faissner 2001; Jones and Jones 2000). In mammals, the family consists of four members namely tenascin-C, $-\mathrm{R},-\mathrm{X}$ and $-\mathrm{W}(-\mathrm{N})$. The macromolecular structures of the different tenascin monomers are highly alike as they follow the same modular arrangement. They are built of an amino-terminal cysteine-rich oligomerization region composed of three to four $\alpha$-helical heptad repeats, EGF-like elements, fibronectin type III-repeats (FN III) and a carboxyl-terminal fibrinogen-like globular domain.

The heptad domains allow an N-terminal association of the individual subunits that primarily form homotrimers. In tenascin- $\mathrm{C}$ and tenascin- $\mathrm{W}$, an additional cysteine residue in this region permits these trimers to further assemble into large hexameric structures, the so-called hexabrachions. Although this cysteine is also present in tenascin- $R$, only trimers of this ECM molecule have been observed so far.

While the number of EGF-like repeats varies only between the different tenascins, some of the FN III domains are also subjected to alternative splicing. Since different combinations of these variable FNIII repeats are possible, several isoforms of the individual tenascins exist (Jones and Jones 2000). For instance, the tenascin-C monomers bear 14.5 EGF-repeats plus 17 FN III repeats, 9 of which can be alternative spliced. As a result, up to 27 different tenascin-C transcripts may be expressed during mouse brain development (Joester and Faissner 1999), each subunit comprising molecular weights in the range of $180-300 \mathrm{kDa}$. In contrast, tenascin-R, which includes $4.5 \mathrm{EGF}$ and 9 FN III repeats, gives rise only to two splice variants of 180 and $160 \mathrm{kDa}$ per subunit. This difference depends on the presence or absence of a supplementary FN III module between the FN III-repeats 5 and 6 (Fuss et al. 1993). Alternative splicing seems also to generate different isoforms of Tn-X (Ikuta et al. 1998) and Tn-W/Tn-N, the latter representing variants originating from the same gene (Neidhardt et al. 2003; Scherberich et al. 2004). Because the neural expression of $\mathrm{Tn}-\mathrm{W} / \mathrm{Tn}-\mathrm{N}$ is currently still rather controversial (Neidhardt et al. 2003; Scherberich et al. 2004) and because $\mathrm{Tn}-\mathrm{X}$ does not reach significant levels in the central nervous system (Matsumoto et al. 1994), we will focus in the following only onto the two other tenascin-family members.

Both, tenascin- $\mathrm{C}$ and tenascin- $\mathrm{R}$ bind to a wealth of extracellular matrix and cell surface ligands (Jones and Jones 2000). These interactions are mainly mediated by the FN III modules. The majority of the cellular receptors for tenascin-C and tenascin-R belong to the integrins, to the cell surface heparan sulfate proteoglycans (syndecans, glypicans) or to the cell adhesion molecules of the immunoglobulin superfamily (Ig-CAMs contactin/F11/F3, axonin/TAG-1 and neurofascin). Other cell surface binding partners are annexin II and the receptor protein tyrosine phosphatase (RPTP- $\zeta / \beta)$. Albeit of uncertain physiological relevance, a low affinity of the EGF-like repeats of Tn-C for EGF-receptors has also been reported (Swindle et al. 2001). Among the major ECM binding partners of these tenascins are fibronectin, phosphacan and particularly lecticans. 
Supramolecular assembly

The ability of the brain ECM-components to selectively aggregate, leads to the establishment of large, relatively loose and flexible meshworks where hyaluronan acts as backbone. The current concept of supramolecular organization and assembly is mainly based on affinity measurements in vitro (mentioned before) and on recent rotary shadowing electron micrographs displaying the corresponding large multi-molecular complexes (Lundell et al. 2004). In this model, filamentous hyaluronan-molecules extruding from the neuronal cell membrane associate first with the G1 domains of distinct lecticans and link proteins that stabilize the complex. At the other end of the lectican core protein, the G3 domains engage in an interaction with one of the arms of the tenascin oligomers. This way tenascins may cross-link up to three (Tn-R) or up to six lecticans (Tn-C) and consequently bridge neighboring hyaluronan/lectican/ link protein-complexes to complete the extracellular network. Supposing that the different components are proportionally expressed, the mesh size of this structure will be determined by the length of the tenascin arm, the distance between the lectican G1/link protein-aggregates along the hyaluronan molecules and most importantly by the dimension of the lectican core protein. Hence, the network would become roughly twice as dense by replacing for instance the V0 isoform of versican by the V2 variant and switching from $\mathrm{Tn}-\mathrm{C}$ to $\mathrm{Tn}-\mathrm{R}$. Along with the change of lectican expression, the proportion of negatively charged carbohydrates and consequently the amounts of attracted water and cations may alter the gel-like properties of the extracellular matrix that occupies the intercellular spaces within the central nervous system. Indeed, the estimated change of the extracellular volume from roughly $40 \%$ in the developing brain to about $20 \%$ in adults (Nicholson and Sykova 1998) may at least partly be linked to the general tendency to express smaller lectican variants in the course of tissue maturation.

\section{Expression and distribution}

Gaining a clear insight into the expression and distribution of ECM components in development and adulthood has not been an easy task as especially antibodies widely employed in the earlier immunohistochemical studies were often not monospecific. Since ex vivo isolates of the highly glycosylated molecules were frequently used for immunization, several monoclonal antibodies have recognized carbohydrate epitopes, which could be found in glycans of several glycoproteins and/or were sometimes only present in subfractions of a particular ECM component (Lander et al. 1997; Matthews et al. 2002; Yamagata et al. 1993; Zako et al.
2002). Another cause for antibody cross-reactivity has also been the high protein sequence conservation, as in the G1 and G3 domains of the lecticans, and the consequent epitope sharing (Bignami et al. 1993; Perides et al. 1993; Yamada et al. 1997b). With the increasing availability of cDNAs and the advent of recombinant expression systems in bacteria, however, antibody production could be directed against more selective sites in little or non-glycosylated regions of the proteins (Milev et al. 1998b; Schmalfeldt et al. 1998; Zimmermann et al. 1994) (Fig. 1). Consequently, a set of highly specific and sensitive polyclonal antibodies with well-defined immunoreactivity has revealed a more consistent picture of ECM expression.

Tenascins $\mathrm{C}$ and $\mathrm{R}$, phosphacan, most of the link proteins and all lecticans, including alternative splice-variants, are at some stage present in the central nervous system (Bandtlow and Zimmermann 2000; Jones and Jones 2000; Rauch 2004; Yamaguchi 2000). While Tn-R, phosphacan, HAPLN2/Bral1, HAPLN4/Bral2, brevican, neurocan and versican $\mathrm{V} 2$ are uniquely expressed in brain and spinal cord, Tn-C and the versican isoforms V0, V1 and V3 are also found in many mesenchymal tissues during embryogenesis and later in association with remodeling processes induced by, e.g., injury, neovascularization, inflammation or neoplasia. Likewise, aggrecan and HAPLN1/Crtl1, which participate in the establishment of some specialized brain ECMs, are primarily components of developing and mature cartilage. Finally, hyaluronan, which interacts with all the lecticans, displays the widest tissue distribution, being (also outside the nervous system) most abundantly produced by morphogenetically active zones during development and adult remodeling processes (Toole 2001, 2004).

Juvenile matrix type

During late embryonic and early postnatal phases of mammalian development, a juvenile type of extracellular matrix is initially formed in the CNS (Fig. 2). It mostly consists of hyaluronan, neurocan, versican V0, versican V1, tenascinC and HAPLN1/Crtl1 (Milev et al. 1998b; Rauch 2004). In addition, prominent CNS-expression of aggrecan has been reported in chick embryos (Schwartz and Domowicz 2004), while only very small amounts have been detected in prenatal rodent brains (Matthews et al. 2002; Milev et al. 1998c). Cellular origin of neurocan and the large versican variants are neurons (Engel et al. 1996; Yamagata and Sanes 2005), whereas aggrecan appears to be mainly expressed by cells of astroglial lineage at this early time point (Domowicz et al. 2008). The transient deposition of neurocan and versican V0/V1, peaks in rats shortly after birth (Fig. 3) (MeyerPuttlitz et al. 1995; Milev et al. 1998a). Preferential accumulations are the marginal zone and the subplate of the 
Fig. 2 Immunohistochemical analyzes of the lectican distribution in the head region of E18.5 mouse embryos. Note the strong brain-specific staining of antibodies against neurocan. The antibodies against versican detect at this time point mainly the versican splice-variants $\mathrm{V} 0$ (GAG- $\alpha$ and GAG- $\beta$ reactive) and $\mathrm{V} 1$ (only GAG- $\beta$ reactive). These versicans are deposited in the CNS and in most of the mesenchymal tissues of the embryo. Aggrecan is practically absent from the brain, but is strongly expressed in cartilaginous tissues. No brevican staining can be detected at this embryonic stage. Sagittal sections. Bar $100 \mu \mathrm{m}$
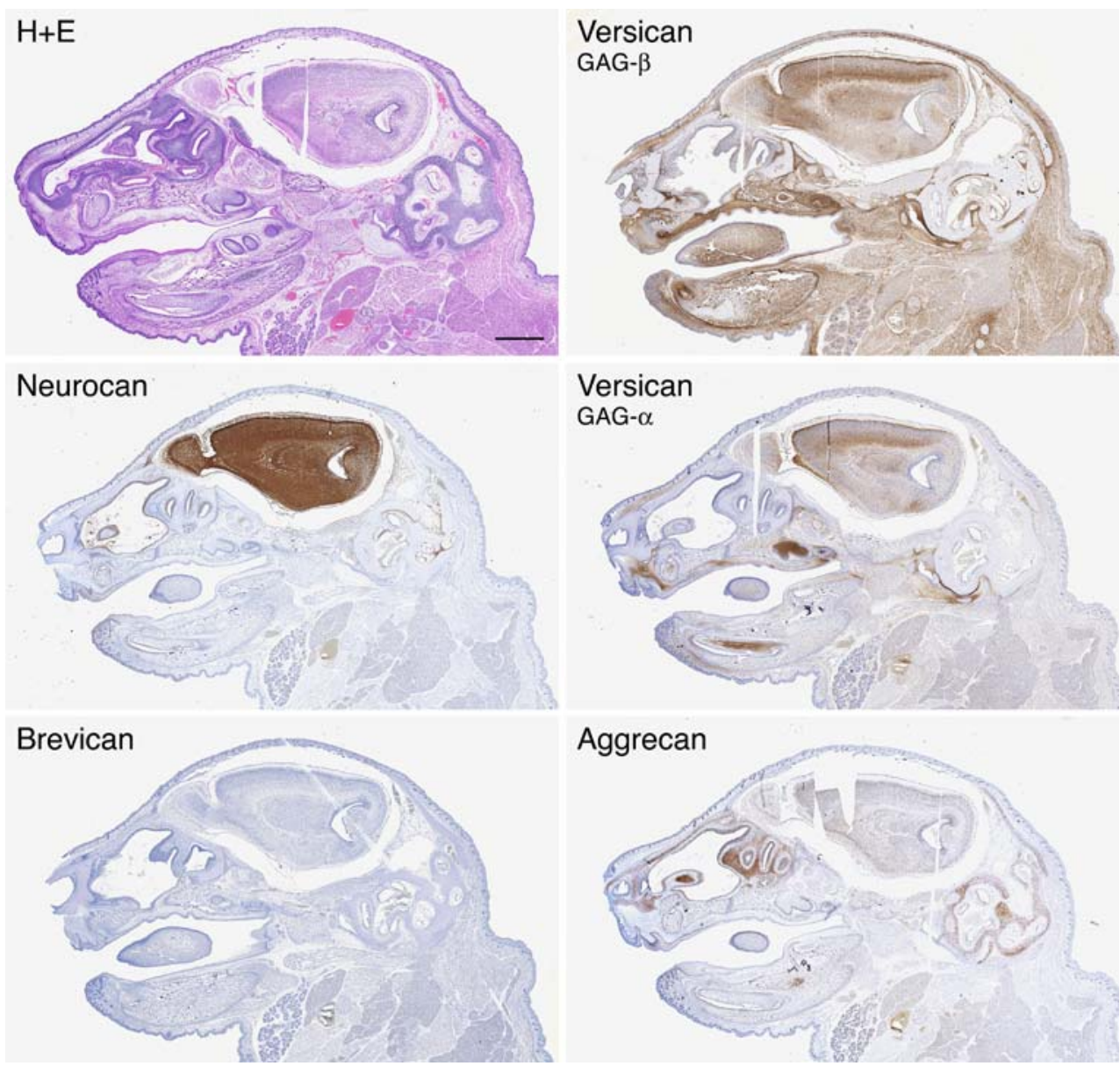

neocortex, parts of the hypothalamus, the amygdala and the developing hippocampus and dentate gyrus (Meyer-Puttlitz et al. 1996; Miller et al. 1995; Popp et al. 2003). Early postnatally, neurocan and the versican isoforms $\mathrm{V} 0$ and $\mathrm{V} 1$ are also found in the presumptive white matter and in the internal granule cell layer of the cerebellum (Meyer-Puttlitz et al. 1996; Popp et al. 2003). Starting from the second week after birth they are down-regulated and finally only persist in a few specialized locations in the adult CNS.

The time course of this early lectican expression is paralleled by their ligands, hyaluronan and the HAPLN1/Crtl1 link protein. In fact, the content of hyaluronan peaks in rodent brain shortly after birth, being subsequently reduced to one-fourth of its maximal level in the adult tissue (Margolis et al. 1975). In the developing cerebellum, hyaluronan is mostly present in the granular cell layer and prospective white matter (Ripellino et al. 1988), where it seems to be organized into extracellular arrays of fiber-like structures (Baier et al. 2007). There is evidence that glial cells synthesize hyaluronan in the early phase of the CNS formation (Deyst and Toole 1995), the hyaluronan synthase responsible for its production at this early stage has yet to be identified. Similar to hyaluronan, HAPLN1/Crtl1, which may stabilize the interaction of hyaluronan with neurocan, versican and aggrecan, is up to about postnatal day 10 increasingly expressed and then gradually diminishes in the maturating nervous tissue (Hirakawa et al. 2000).

A relatively early CNS expression is also observed for the glia-derived ECM glycoprotein Tn-C. It first accumulates around the fibrous processes of radial and Bergmann glial cells that direct the migration of neuronal precursors during cortical and cerebellar development, respectively (Crossin et al. 1986; Prieto et al. 1990). In rodents, it is rather widely distributed shortly after birth and displays at least in the cerebral cortex, hippocampus and cerebellum partial overlaps with neurocan and versican V0/V1 depositions (Bartsch et al. 1992; Laywell and Steindler 1991; Meyer-Puttlitz et al. 1996; Popp et al. 2003). Particularly intriguing is the transient association of $\mathrm{Tn}-\mathrm{C}$ with the glial boundary tissues surrounding the functional sets of neurons, like for instance the vibrissae-related barrel fields of the developing somatosensory cortex (Steindler et al. 1989). About 2-3 weeks after birth, Tn-C levels decrease continuously, maintaining only a significant expression level in the neurogenetically active areas of the adult brain that encompass the subependymal zone and the hippocampus 

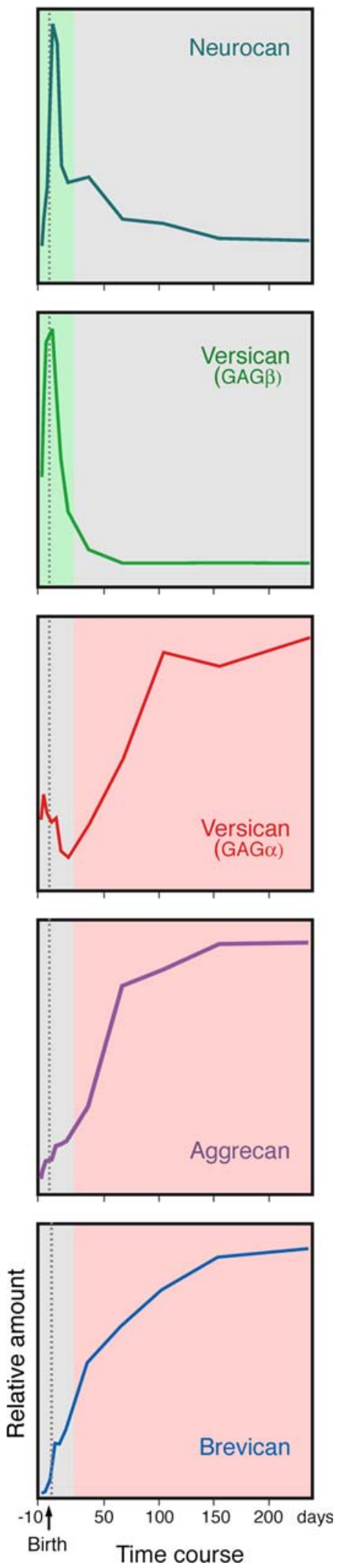

Fig. 3 Time course of lectican levels in extracts of embryonic and postnatal rat brains. Note the transition from the expression of the juvenile-type of matrix to its mature form around postnatal day 20. Diagrams adapted from (Milev et al. 1998b)
(Bartsch et al. 1992; Dorries and Schachner 1994; Gates et al. 1995; Thomas et al. 1996).

Mature matrix type

Initiating about 2 weeks after birth, a major remodeling process takes place (Fig. 3), which replaces most of the juvenile type of matrix by its mature form (Rauch 2004). This exchange transforms the relatively loose embryonic and early postnatal ECM to a significantly firmer meshwork, which is subsequently maintained throughout adulthood. The large majority of the early matrix components are along the conversion substituted by a different, but homologous set of ECM proteins that include versican V2, aggrecan, brevican, phosphacan, tenascin-R and the brain link proteins HAPLN2/Bral1 and HAPLN4/Bral2 (Bekku et al. 2003; Hirakawa et al. 2000; Meyer-Puttlitz et al. 1995; Milev et al. 1998b; Pesheva et al. 1989).

In the adult CNS, various combinations of lecticans and link protein, which are generally associated with hyaluronan, Tn-R and phosphacan condense at some strategic locations (Fig. 4.). Versican V2 and the secreted brevican isoform emerge around the second and third week postpartum and subsequently evolve to the predominant constituents in the adult brain and spinal cord (Schmalfeldt et al. 1998; Yamaguchi 1996). Matrices that contain mainly versican V2 and some brevican are most prevalent in the white matter surrounding the myelinated fibers of all calibers (Ogawa et al. 2001; Schmalfeldt et al. 2000). Particularly dense accumulation of versican V2, HAPLN2/Bral1, Tn-R and phosphacan appear as ring-like structures around the CNS nodes of Ranvier (Dours-Zimmermann et al. unpublished; Melendez-Vasquez et al. 2005; Oohashi et al. 2002; Pesheva et al. 1989; Xiao et al. 1997). Origins of the Tn-R and versican V2 deposits in the white matter are primarily oligodendrocytes and their precursors (Asher et al. 2002; Pesheva et al. 1989; Schmalfeldt et al. 2000), while HAPLN2/Bral1 expression has been attributed to neurons (Oohashi et al. 2002) or oligodendrocytes (Carulli et al. 2006). Interestingly, the brevican expression shifts at the end of myelination from oligodendroglial to astrocytic lineage in the white matter (Ogawa et al. 2001). Starting from postnatal day 28 , astrocytes seem to give rise to another particularly brevican-rich zone that forms after completion of the neuronal migration in the granular cell layer of the rat cerebellum. This more compact extracellular matrix ensheathes cerebellar glomeruli, in which the incoming mossy fibers contact the local neuronal processes (Yamada et al. 1997a).

The by far best studied extracellular matrix condensation in the adult central nervous system is the perineuronal net (PNN). This lattice-like structure engulfs the cell bodies, proximal dendrites and axon initial segments of specific 


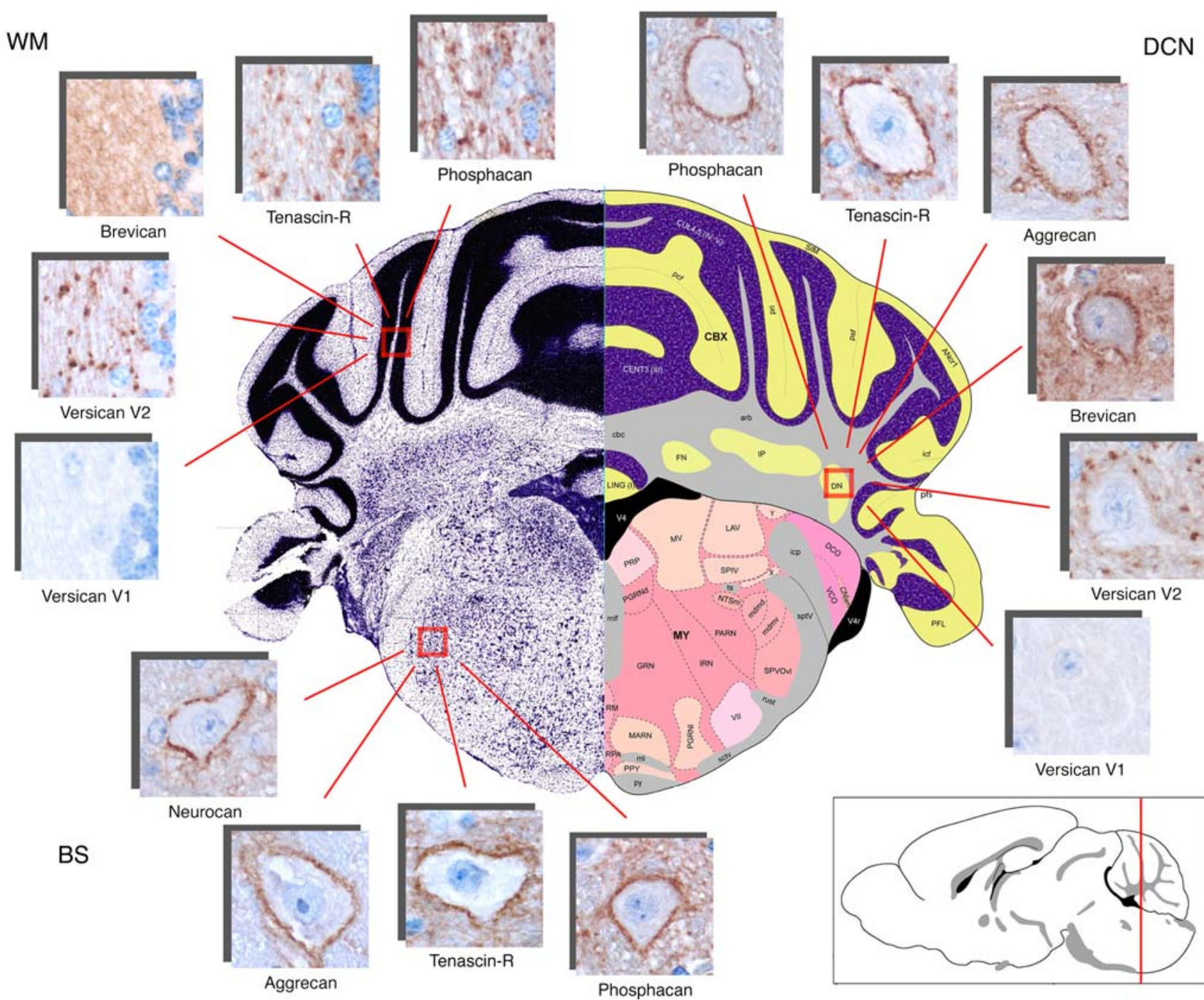

Fig. 4 Localization of lecticans and tenascins in coronal sections through adult cerebellum and medulla at Bregma $-6.18 \mathrm{~mm}$. Note the perineuronal net staining of aggrecan, tenascin-R and phosphacan in the deep cerebellar nuclei $(D C N)$ and the brain stem $(B S)$. Brevican and neurocan are only present in some of the PNNs. Versican V2, which stains exclusively with GAG- $\alpha$-, but not with GAG- $\beta$-specific antibod-

subsets of neurons and embeds, with exception of the synaptic clefts, the presynaptic boutons that contact them (Bruckner et al. 1993, 2006; Celio and Blumcke 1994; Celio et al. 1998; Galtrey and Fawcett 2007; Murakami and Ohtsuka 2003; Rhodes and Fawcett 2004; Yamaguchi 2000). PNNs can be observed in many areas of the CNS including the cerebral cortex, the hippocampus, the thalamus, the cerebellum, the brain stem and the spinal cord. They most frequently surround parvalbumin-expressing GABAergic interneurons and certain cortical pyramidal neurons, as well as projection and large motor neurons of the brain stem and spinal cord. The formation of perineuronal nets occurs relatively late in postnatal development (in rodents $2-5$ weeks after birth) and coincides with the end- ies is accumulating at the nodes of Ranvier in the white matter $(W M)$, while brevican staining is rather diffused in the myelinated fiber tracts. Versican V0 and V1, which are recognized by the GAG- $\beta$-specific antibodies are absent from these brain regions in adult mice. Graphics modified from the Allen Brain Atlas (http://www.brain-map.org) (Lein et al. 2007)

ing of the experience-dependent refinement of the synaptic network and the closure of the critical period, e.g., in the visual system and spinal cord (Guimaraes et al. 1990; Kalb and Hockfield 1988, 1990; Pizzorusso et al. 2002).

This specialized matrix consists of hyaluronan, different lecticans, the link proteins HAPLN1/Crt11 and HAPLN4/ Bral2, Tn-R, and phosphacan (Asher et al. 1995; Bekku et al. 2003; Bruckner et al. 2000; Carulli et al. 2006; Haunso et al. 1999; Maeda et al. 1995). The perineuronally accumulating hyaluronan is synthesized by HAS2 and HAS3 expressed in the net-carrying neurons, while HAS1 is generally absent from the CNS (Carulli et al. 2006, 2007). During the PNN-formation, HAS3 may slightly precede HAS2. The expression of both of these hyaluronan 
synthases is subsequently attenuated, but pertains throughout adulthood.

Among the lectican family members, aggrecan is the most common perineuronal net component. Although present in all PNNs, it may contribute to a certain sub-specialization by varying its glycan structures between distinctive sets of neuronal coats (Matthews et al. 2002). Brevican and neurocan display in many CNS regions an expression pattern similar to aggrecan (Fig. 4) and there is indeed some evidence that they co-localize within the same perineuronal structure (Carulli et al. 2006; Galtrey et al. 2008). At least hyaluronan, aggrecan and $\mathrm{Tn}-\mathrm{R}$ seem to be rather uniformly distributed within a single net covering the cell body, proximal dendrites and the axon initial segment (AIS) irrespective of the presence of synapses (Bruckner et al. 2006). In contrast, a certain preference of brevican deposition around the AIS has been observed in neuronal cell cultures (Hedstrom et al. 2007; John et al. 2006). Using a monoclonal antibody (12C5) against the hyaluronan-binding G1 domain of versican, immunohistological examinations of brain and spinal cord sections have also suggested that the fourth lectican member is present in PNNs (Carulli et al. 2006; Deepa et al. 2006). Surprisingly, none of our antibodies against the two GAG-attachment regions (Fig. 1) has displayed a similar perineuronal net staining (Fig. 4). It is therefore conceivable that the 12C5 antibody, in fact does not detect intact versican V2 in the PNNs, but rather a proteolytic remnant of the early postnatal versican V0 and V1 expressions that correspond to the versican fragment, formerly named as glial hyaluronate-binding protein (GHAP) or hyaluronectin (Delpech and Halavent 1981; Perides et al. 1989). Also neurocan in the PNNs may at least partly be present in form of a hyaluronan-binding truncation product (Neurocan- $N$ ) (Deepa et al. 2006), which eventually has become trapped after the conversion of the juvenile matrix.

No matter whether the lecticans are intact or truncated, their interactions with hyaluronan seem to be either stabilized by HAPLN1/Crtl1 or by HAPLN4/Bral2 (Bekku et al. 2003; Carulli et al. 2006, 2007). Both of these link proteins form an integral part of perineuronal nets. Whereas HAPLN1/Crtl1 seems to bind to its classical partner aggrecan and probably also to neurocan or neurocan- $N$, there is some indication from knockout mice that brevican may be required for the PNN localization of HAPLN4/Bral2 (Bekku et al. 2003).

Most of the perineuronal net constituents seem to be expressed by the engulfed neurons themselves (Carulli et al. 2006). Nonetheless, contributions from surrounding astrocytes that extend cellular processes into the reticular structure cannot be excluded (Carulli et al. 2007). This concerns particularly brevican and to some extent also neurocan, which may be produced bilaterally by the ensheathed neurons and the contacting astrocytes. Co-culture experi- ments of primary hippocampal neurons and glial cells indeed revealed that the perineuronal deposits of brevican are in vitro primarily astrocyte-derived (John et al. 2006), although perineuronal net-like structures develop apparently also in the virtual absence of glial cells (Miyata et al. 2005).

Lesion-associated reactive matrix

Once established, the composition of the mature type of extracellular matrix is rather stable with little or no turnover of their components. This changes, however, radically, when lesions to the adult central nervous system occur. Under these circumstances, the expression of various extracellular matrix molecules is highly up-regulated and major depositions are observed in and around the lesion site, in particular, in association with the glial scar tissue that forms (Bradbury and McMahon 2006; Galtrey and Fawcett 2007; Gonzenbach and Schwab 2008; Morgenstern et al. 2002; Zurn and Bandtlow 2006). The freshly produced ECM components may be secreted by reactive astrocytes, oligodendrocyte precursors, microglia/macrophages and eventually by meningeal cells. The lesion and consequent reactive processes induce a matrix accumulation that strongly resembles the juvenile-type of meshwork previously observed during early nervous system development. For instance, surgical incisions in the cerebral cortex or spinal cord provoke a relatively fast and transient up-regulation of Tn-C and neurocan (Asher et al. 2000; Haas et al. 1999; Jones et al. 2003; Laywell et al. 1992; Matsui et al. 2002; McKeon et al. 1999; Tang et al. 2003). Also the expression of versican V2, brevican and phosphacan appear to be affected. Yet, recent reports about alterations in the production of versican V2 (direction of regulation) and brevican (timing) are somewhat controversial (Asher et al. 2002; Jones et al. 2003; Tang 2003). There are nevertheless indications that the lecticans brevican, aggrecan and versican V2 follow the time course of phosphacan, whose content first diminishes during the acute phase and then increases in a late attempt to restore the mature type of matrix at the injury site (Lemons et al. 2001; Tang et al. 2003).

A similar post-traumatic upregulation of $\mathrm{Tn}-\mathrm{C}$ and lecticans has also been observed after disruption of sensory axons at the dorsal root (Beggah et al. 2005; Pindzola et al. 1993). Importantly, this type of lesion near the PNS/CNS interface lacks a scar formation within the CNS, but still leads to a reactive gliosis in the dorsal root entry zone (DREZ) and Wallerian degeneration of the central axon branches, now separated from their cell bodies. Despite the absence of a glial scar tissue, elevated depositions of neurocan and versicans (also V1 isoform) are prominent in the DREZ suggesting that the remodeling process temporally 
reactivates a juvenile matrix-like expression profile analogous to direct damages to the CNS.

\section{Matrix turnover}

The rapid switch from embryonic and early postnatal extracellular matrices to their mature form in the normal adult CNS (Rauch 2004), the fast disappearance of CSPGs from the predestined axonal pathways observed in the developing periphery (Landolt et al. 1995; Oakley and Tosney 1991), as well as the reactive changes following nervous system lesions (Galtrey and Fawcett 2007; Zurn and Bandtlow 2006) cannot solely be attributed to adjustments in the ECM expression patterns, but must also depend on highly active proteolytic processes (Agrawal et al. 2008; Ethell and Ethell 2007; Flannery 2006; Gottschall et al. 2005; Milward et al. 2007; Porter et al. 2005). The selective turnover of lecticans may in this context be essential for altering the cell migration and axon growth properties of many nervous tissues. Metalloendopeptidases of the ADAMTS family seem to be primarily responsible for the lectican catabolism (ADAMTS: a disintegrin and metalloproteinase with thrombospondin motifs). Conversely, matrix metalloproteases (MMPs) may only play a subordinate role in the proteoglycan degradation, but they could preferentially target the link proteins and tenascins of the central nervous system. In any case, the proteolysis is tightly controlled by the tissue inhibitors of metalloproteinases (TIMPs), which are physiological antagonists of both enzyme types, MMPs (TIMP-1 to -4) and ADAMTSs (TIMP-3).

Various ADAMTS-enzymes cleave lecticans at a few specific sites in vitro and corresponding digestion products have been identified in vivo (Flannery 2006; Gottschall et al. 2005; Porter et al. 2005). The secreted ADAMTSs are close relatives of the cell membrane-bound ADAM metalloproteases. ADAMs and ADAMTSs are expressed as zymogens containing a prodomain and a zinc-binding catalytic element linked to a disintegrin-like motif. In ADAMTSs, several additional modules may control tissue localization and contribute to the substrate specificity. This C-terminal set of ancillary domains includes a central thrombospondin type I repeat, a cysteine-rich region, a spacer element and several supplementary thrombospondin motifs in most of the family members. The ADAMTS-zymogens are in the trans-Golgi or at the cell surface activated by $\mathrm{N}$-terminal propeptide cleavage mediated by furin or furin-like convertases. Additional proteolytic or autocatalytic removal of a C-terminal portion has been demonstrated to modulate the enzymatic activity of some of these metalloproteases (Gao et al. 2002; Rodriguez-Manzaneque et al. 2000; Zeng et al. 2006).

Five ADAMTS sites have been characterized in the aggrecan core protein (Caterson et al. 2000; Lemons et al.
2001), two to four in the proteoglycan isoforms of versican (V2-V0) (Jonsson-Rylander et al. 2005; Sandy et al. 2001; Westling et al. 2004) and one in brevican (Matthews et al. 2000; Yamada et al. 1995). Interestingly, in all of these lecticans one ADAMTS-site is located next to the globular G1-domain allowing the selective release of the large GAG-carrying portions from the complex with hyaluronan and link proteins. Finally, also neurocan, which is in adult tissues often present in form of two well-defined N- and Cterminal fragments, may be cleaved by an ADAMTS- or MMP-protease. Based on comparisons of known substrates, specific sites for by MMP-2- and ADAMTS-processing have been postulated. Whereas MMP-2 indeed cleaves neurocan in vitro, the susceptibility to ADAMTSdigestion still has to be confirmed in an experimental setting (Sandy et al. 2001; Turk et al. 2001).

Among the 19 ADAMTSs, seven exhibit cleavage capacity towards lecticans (ADAMTS- $1,-4,-5,-8,-9,-15$ and -20; ADAMTS-5 and -11 are identical). The classical aggrecanases are ADAMTS-4 and -5 (Abbaszade et al. 1999; Tortorella et al. 1999). Albeit less efficient, aggrecanprocessing activities have also been observed of ADAMTS-1, -8, -9 and -15 (Collins-Racie et al. 2004; Flannery 2006; Kuno et al. 2000; Somerville et al. 2003). At least four ADAMTS-proteases including ADAMTS-1, $-4,-9$ and -20 recognize versican substrates in vitro (Sandy et al. 2001; Silver et al. 2008; Somerville et al. 2003; Westling et al. 2004), whereas only cleavage by ADAMTS-4 and -5 has been demonstrated for brevican (Matthews et al. 2000; Nakada et al. 2005; Nakamura et al. 2000).

Until now, only a few studies have explored the expression of distinct ADAMTSs during nervous system development and virtually no data are available for peri- and early postnatal phases that are particularly interesting regarding the remodeling of the neural ECM. From the limited insights one can currently conclude, that ADAMTS- 1 and -9 are expressed relatively early in the embryonic CNS (Gunther et al. 2005; Jungers et al. 2005; Thai and IruelaArispe 2002), while ADAMTS-4 appears only in adult nervous tissues (Abbaszade et al. 1999; Jungers et al. 2005). Moderate to low expression of ADAMTS-4, for instance has been detected in pyramidal neurons of various cortical areas and in granule cells of the dentate gyrus in normal adult brain (Yuan et al. 2002).

This base-expression of ADAMTSs rises considerably in the presence of different types of lesions. After a kainateinduced excitotoxic insult, a transient up-regulation of ADAMTS-4 and ADAMTS- 1 coincides with a marked increase of brevican proteolysis (Mayer et al. 2005; Yuan et al. 2002). A similar reaction is also observed in an experimental model of cerebral ischemia (Cross et al. 2006). Moreover, motor axon disruption induces the ADAMTS-1 production in the affected neurons (Sasaki et al. 2001) and 
there is growing evidence that the same enzyme is also over-expressed in association with various neurodegenerative disorders (Miguel et al. 2005; Satoh et al. 2000). In addition, glioblastomas display elevated levels of brevican and its proteolytic fragments (Nutt et al. 2001) are associated with an increased expression of ADAMTS-5 and, although somewhat controversial, possibly also with ADAMTS-4 (Held-Feindt et al. 2006; Nakada et al. 2005). This close relationship between ECM remodeling and ADAMTS expression under traumatic and pathogenic conditions, provides an indirect indication for an analogous functional involvement of ADAMTSs in the matrix conversion of normal neural development.

\section{Putative functions}

The progress in unraveling the precise functions of the extracellular matrix in the central nervous system has for long been rather slow due to the high structural variability of its main constituents and the great complexity of the dynamic remodeling process involved in normal development and disease conditions. Albeit correlations of the distribution of specific ECM components with cellular processes like proliferation, migration, axonal growth or synapse formation have been very valuable for gaining insights into the putative functions in vivo, they may have been somewhat distorted by the fact that most antibodies used in these studies are unable to discriminate between intact and ADAMTS- or MMP-processed forms of a particular molecule. This distinction could be of considerable importance as the specific cleavage may attenuate or even neutralize certain ECM functions without becoming apparent in the immunohistological stainings.

Moreover, partial overlapping rather than completely different functions of structurally related matrix proteins may be responsible for the unexpectedly mild phenotypes of several knockout mice, while the absence of potential key components has in contrast resulted in embryonic or perinatal lethality that prevents the study of their role in the mainly postnatal neural development (Table 2). Nevertheless, evidence for an extracellular matrix involvement in neural migration, axon guidance, plasticity restriction and fiber tract stabilization has in recent years come from various in vitro and in vivo observations.

\section{Axon growth inhibition}

Phosphacan and all lecticans of the central nervous system inhibit in their intact form axonal growth in vitro (Bandtlow and Zimmermann 2000; Yamaguchi 2000). This functional property appears to be mostly core protein-dependent in versican V0, V1 and V2 (Dutt, Stöckli and Zimmermann unpublished; Niederöst et al. 1999; Schmalfeldt et al. 2000;), neurocan (Margolis et al. 1996) and phosphacan (Maeda and Noda 1996), whereas no inhibition of brevican (Yamada et al. 1997a) and cartilage-derived aggrecan (Snow et al. 1990) has been detected after chondroitinase ABC digestion. Notably, we also observed two- to threefold reductions, but never an abolition of the inhibitory capacity of versican V2 in stripe choice experiments after complete glycosaminoglycan-removal (Schmalfeldt et al.

Table 2 Available ECM-knockout mouse strains

\begin{tabular}{|c|c|c|}
\hline Gene & Viability & CNS phenotype \\
\hline Brevican (Bcan) & Normal & Reduced LTP \\
\hline Neurocan (Ncan) & Normal & Reduced LTP \\
\hline Versican (Vcan/hdf-strain) & Die at E10.5 & - \\
\hline Aggrecan (Acan/cmd-strain) & Die at birth & ND \\
\hline RPTP- $\beta /$ phosphacan (Ptprz1) & Normal & $\begin{array}{l}\text { Enhanced LTP; impaired recovery from EAE } \\
\text { (transmembrane variants?) }\end{array}$ \\
\hline Tenascin-R (Tnr) & Normal & $\begin{array}{l}\text { Aberrant PNNs; reduced conduction velocity; } \\
\text { disturbed neuroblast migration in olfactory bulb; } \\
\text { some behavioral abnormalities }\end{array}$ \\
\hline Tenascin-C $(\operatorname{Tn} c)$ & Normal & Reduced LTP; mild behavioral abnormalities \\
\hline HAPLN1/Crt11 (Hapln1) & Die at birth & ND \\
\hline HAS2 (Has2) & Die at E10.5 & - \\
\hline HAS3 (Has3) & Normal & ND \\
\hline
\end{tabular}

LTP Hippocampal long-term potentiation, EAE experimental autoimmune encephalomyelitis, $P N N$ perineuronal net, $N D$ not described Brevican (Brakebusch et al. 2002); neurocan (Zhou et al. 2001); versican (Mjaatvedt et al. 1998); aggrecan (Watanabe et al. 1994); RPTP- $\beta /$ phosphacan (Harroch et al. 2000, 2002; Niisato et al. 2005); TnR (Bruckner et al. 2000; Freitag et al. 2003; Haunso et al. 2000; Montag-Sallaz and Montag 2003; Saghatelyan et al. 2004; Weber et al. 1999); TnC (Evers et al. 2002; Forsberg et al. 1996; Fukamauchi et al. 1996; Kiernan et al. 1999; Saga et al. 1992); HAPLN1/Crt11 (Watanabe and Yamada 1999); HAS2 (Camenisch et al. 2000); HAS3 (Bai et al. 2005) 
2000). This moderate decrease might be related to the partial collapse of the extended core protein structure after elimination of the highly negatively charged chondroitin sulfate side chains.

The axonal growth inhibition is likely dependent on the presence of a pericellular hyaluronan coat that covers many cell types and often includes variable amounts of lecticans, link proteins and tenascins (Evanko et al. 2007). Synthesis of hyaluronan alone promotes in various cell types the formation of plasma membrane protrusions (Kultti et al. 2006; Rilla et al. 2008). It is therefore conceivable that a coat containing exclusively hyaluronan has a similar effect in generating growth cone filopodia exploring the environment at the tip of growing axons. In situations, in which these filopodia encounter areas expressing lecticans, they may incorporate the CSPGs into the pericellular hyaluronan structure and consequently increase the hydration capacity and thus the thickness of their coat. Depending on the extent of this coat swelling, the contacts to the surface of neighboring cells or the extracellular matrix may be increasingly compromised by sterical hindrance. Accordingly, the advancing growth cone should slow down, turn away or retract from the lectican-containing zones. Furthermore, the expression level, core protein size and carbohydrate substitution of the encountered lecticans would control the coat dimensions and thus, modulate the inhibitory effect. In line with this hypothesis are the concentration-dependency of the versican inhibition (Schmalfeldt et al. 2000) and a certain tendency to accentuate the effect by using larger splicevariants in vitro (Dutt, Stöckli and Zimmermann, unpublished). In addition, neurons may regulate the coat size by the extent of the hyaluronan synthesis and/or by secreting ADAMTS-proteases, which would reduce the inhibitory activity through release of the GAG-carrying core protein portions from the pericellular structure.

While high-versican concentrations provoke retraction, low concentrations still allow a reduced growth, but promote enlargement of presynaptic varicosities in chick retinal axons in vitro (Yamagata and Sanes 2005). This finding is corroborated by RNA interference experiments in vivo, where depletion of versican causes a significant size reduction of the varicosities in the retinal arbors of the optic tectum suggesting that low-versican expression attenuates axonal growth and induces lamina-specific presynaptic maturation. Conversely, high expression of versican V0/V1 may also contribute to the formation of molecular barriers that block axon extension and may in addition, direct migratory neural crest cells in the developing peripheral nervous system (Dutt et al. 2006; Landolt et al. 1995; Oakley and Tosney 1991). Unfortunately, these suspected modulator functions of the V0/V1 isoforms cannot be verified in versican null mice ( $h d f$ strain), as they suffer from problems in heart segmentation and consequently die early, at around embryonic day 10.5 (Mjaatvedt et al. 1998).

Although the highest matrix protein expression in the CNS during early neural development has been attributed to $\mathrm{Tn}-\mathrm{C}$ and neurocan, their in vivo functions in the juvenile-type of matrix are still largely unknown. Single knockouts of neurocan and Tn-C showed no apparent anatomical abnormalities in the CNS (Steindler et al. 1995; Zhou et al. 2001). A potential compensation by up-regulation of the closely related brevican or Tn-R, respectively, has not been observed. Nonetheless, recent generation of a Tn-C, Tn-R, neurocan and brevican quadruple knockout suggested a partial replacement of the tenascins by fibulin- 1 and -2 , which are generally not expressed in the brain parenchyma, but may similarly cross-link the C-terminal domains of the remaining lecticans (Rauch et al. 2005). This complex may however, be less stable as suggested by the partly disturbed structure of the perineuronal nets in these quadruple and in the Tn-R single knockout mice (Bruckner et al. 2000; Haunso et al. 2000; Rauch et al. 2005; Weber et al. 1999).

\section{Regulation of plasticity}

There are increasing indications that the transition from the juvenile type of matrix to its mature form terminates the highly dynamic periods of cell and axonal migrations and restricts plasticity and regeneration in the adult central nervous system (Galtrey and Fawcett 2007; Rauch 2004). In white matter, specialized matrices rich in brevican and versican V2 contribute to axon growth inhibitory environment associated with CNS myelin (Niederöst et al. 1999) and possibly prevent abnormal axon branching by accumulating at the nodes of Ranvier. In addition, the establishment of perineuronal nets seems to stabilize the neuronal circuitry by suppressing the formation of new synaptic contacts (Galtrey and Fawcett 2007; Hockfield et al. 1990; Rauch 2004; Yamaguchi 2000). These speculations that are mostly based on the inhibitory properties of lecticans in vitro, have been further nourished by observations that injections of bacterial chondroitinase into the visual cortex of rats affect the integrity of perineuronal nets and restore ocular dominance plasticity even after closure of the critical period (Berardi et al. 2004; Hooks and Chen 2007; Pizzorusso et al. 2002, 2006). Similarly enhanced plasticity after chondroitinase treatment has been reported from experimental brain and spinal cord injuries (Barritt et al. 2006; Bradbury et al. 2002; Moon et al. 2001). In these studies, the digestion of chondroitin sulfates at the lesion sites resulted in increased axonal sprouting and some axonal re-growth across the normally non-permissive glial scar tissue, which expresses CSPGs abundantly. In addition, in adult brevican and neurocan double-knockout mice, the obstruction of the lectican-rich dorsal root entry 
zone appears to be partly lifted, as a significant number of sensory axons cross back into the DREZ after proximal nerve disruption and subsequent growth stimulation through a late conditioning lesion of the peripheral branch (Quaglia et al. 2008). Because the suppression of a single myelin- or ECM-associated CNS-inhibitor typically leads to less than $10 \%$ robust re-growth of cut axons in all different experimental lesion systems tested (Bradbury and McMahon 2006; Gonzenbach and Schwab 2008; Zheng et al. 2006), such multimodal strategies may be required to achieve an improved neutralization of the inhibition and a more effective promotion of the regenerative response in the CNS.

\section{Other putative functions}

Apart from these putative roles connected to axon growth inhibition, the condensed matrices in the mature central nervous system may take part in axo-glial interactions and regulate the ion homeostasis required for the rapid and timely induction and propagation of action potentials at the axon initial segments (AIS) and at the nodes of Ranvier, respectively (Bruckner et al. 1993, 2006; Hedstrom and Rasband 2006; Poliak and Peles 2003; Salzer 2003). In this context it is interesting to note, that neurocan, brevican, RPTP- $\beta /$ phosphacan and also Tn-C null-mice display certain alterations of hippocampal long-term potentiation (in RPTP- $\beta$ knockout mice probably only linked to transmembrane variants), while a decreased axonal conductance has been measured in the optic nerve of Tn-R mutants (Brakebusch et al. 2002; Evers et al. 2002; Weber et al. 1999; Zhou et al. 2001).

It has also been suggested that proteoglycans in the extracellular meshwork surrounding myelin-free and thus, exposed nodal regions and axon initial segments may be implemented in neuroprotective functions (Miyata et al. 2007; Morawski et al. 2004).

Finally, abrogation of Tn-R expression impairs in adult knockout mice the detachment and radial migration of neuroblasts into the outer layers of the olfactory bulb. In contrast, ectopic expression reroutes the neuroblasts that originate from the subventricular zone of the lateral ventricles and first move tangentially in the rostral migratory stream. This suggests that Tn-R alone may also act as positive cue for adult neuroblast migration (Saghatelyan et al. 2004).

Despite the panoply of putative functions of the extracellular matrix in the nervous system presented in the last years, the picture of its main roles in development and maturation has remained largely fragmented. It is to hope, that after a long period of neglect, the recently renewed research interests will boost the assembly of this fascinating puzzle.
Acknowledgments We thank Holger Moch for support and our labteam for taking care of our diagnostic duties during the writing of this review. Our work has been partly financed by the University of Zurich, the Swiss National Science Foundation and the Velux-Foundation.

\section{References}

Abbaszade I, Liu RQ, Yang F, Rosenfeld SA, Ross OH, Link JR, Ellis DM, Tortorella MD, Pratta MA, Hollis JM, Wynn R, Duke JL, George HJ, Hillman MC Jr, Murphy K, Wiswall BH, Copeland RA, Decicco CP, Bruckner R, Nagase H, Itoh Y, Newton RC, Magolda RL, Trzaskos JM, Burn TC et al (1999) Cloning and characterization of ADAMTS11, an aggrecanase from the ADAMTS family. J Biol Chem 274:23443-23450

Agrawal SM, Lau L, Yong VW (2008) MMPs in the central nervous system: where the good guys go bad. Semin Cell Dev Biol 19:42-51

Asher RA, Scheibe RJ, Keiser HD, Bignami A (1995) On the existence of a cartilage-like proteoglycan and link proteins in the central nervous system. Glia 13:294-308

Asher RA, Morgenstern DA, Fidler PS, Adcock KH, Oohira A, Braistead JE, Levine JM, Margolis RU, Rogers JH, Fawcett JW (2000) Neurocan is upregulated in injured brain and in cytokinetreated astrocytes. J Neurosci 20:2427-2438

Asher RA, Morgenstern DA, Shearer MC, Adcock KH, Pesheva P, Fawcett JW (2002) Versican is upregulated in CNS injury and is a product of oligodendrocyte lineage cells. J Neurosci 22:22252236

Aspberg A, Binkert C, Ruoslahti E (1995) The versican C-type lectin domain recognizes the adhesion protein tenascin-R. Proc Natl Acad Sci USA 92:10590-10594

Aspberg A, Miura R, Bourdoulous S, Shimonaka M, Heinegård D, Schachner M, Ruoslahti E, Yamaguchi Y (1997) The C-type lectin domains of lecticans, a family of aggregating chondroitin sulfate proteoglycans, bind tenascin-R by protein-protein interactions independent of carbohydrate moiety. Proc Natl Acad Sci USA 94:10116-10121

Aspberg A, Adam S, Kostka G, Timpl R, Heinegard D (1999) Fibulin1 is a ligand for the C-type lectin domains of aggrecan and versican. J Biol Chem 274:20444-20449

Bai KJ, Spicer AP, Mascarenhas MM, Yu L, Ochoa CD, Garg HG, Quinn DA (2005) The role of hyaluronan synthase 3 in ventilatorinduced lung injury. Am J Respir Crit Care Med 172:92-98

Baier C, Baader SL, Jankowski J, Gieselmann V, Schilling K, Rauch U, Kappler J (2007) Hyaluronan is organized into fiber-like structures along migratory pathways in the developing mouse cerebellum. Matrix Biol 26:348-358

Bandtlow CE, Zimmermann DR (2000) Proteoglycans in the developing brain-new conceptual insights for old proteins. Physiol Rev 80:1267-1290

Barnea G, Grumet M, Milev P, Silvennoinen O, Levy JB, Sap J, Schlessinger J (1994) Receptor tyrosine phosphatase beta is expressed in the form of proteoglycan and binds to the extracellular matrix protein tenascin. J Biol Chem 269:14349-14352

Barritt AW, Davies M, Marchand F, Hartley R, Grist J, Yip P, McMahon SB, Bradbury EJ (2006) Chondroitinase ABC promotes sprouting of intact and injured spinal systems after spinal cord injury. J Neurosci 26:10856-10867

Bartsch U, Bartsch S, Dorries U, Schachner M (1992) Immunohistological localization of tenascin in the developing and lesioned adult mouse optic nerve. Eur J Neurosci 4:338-352

Beggah AT, Dours-Zimmermann MT, Barras FM, Brosius A, Zimmermann DR, Zurn AD (2005) Lesion-induced differential expression and cell association of neurocan, brevican, versican V1 and V2 in the mouse dorsal root entry zone. Neuroscience 133:749-762 
Bekku Y, Su WD, Hirakawa S, Fassler R, Ohtsuka A, Kang JS, Sanders J, Murakami T, Ninomiya Y, Oohashi T (2003) Molecular cloning of Bral2, a novel brain-specific link protein, and immunohistochemical colocalization with brevican in perineuronal nets. Mol Cell Neurosci 24:148-159

Berardi N, Pizzorusso T, Maffei L (2004) Extracellular matrix and visual cortical plasticity: freeing the synapse. Neuron 44:905-908

Bezakova G, Ruegg MA (2003) New insights into the roles of agrin. Nat Rev Mol Cell Biol 4:295-308

Bignami A, Perides G, Rahemtulla F (1993) Versican, a hyaluronatebinding proteoglycan of embryonal precartilaginous mesenchyma, is mainly expressed postnatally in rat brain. $\mathrm{J}$ Neurosci Res 34:97-106

Bradbury EJ, McMahon SB (2006) Spinal cord repair strategies: why do they work? Nat Rev Neurosci 7:644-653

Bradbury EJ, Moon LD, Popat RJ, King VR, Bennett GS, Patel PN, Fawcett JW, McMahon SB (2002) Chondroitinase ABC promotes functional recovery after spinal cord injury. Nature 416:636-640

Brakebusch C, Seidenbecher CI, Asztely F, Rauch U, Matthies H, Meyer H, Krug M, Bockers TM, Zhou X, Kreutz MR, Montag D, Gundelfinger ED, Fassler R (2002) Brevican-deficient mice display impaired hippocampal CA1 long-term potentiation but show no obvious deficits in learning and memory. Mol Cell Biol 22:7417-7427

Bruckner G, Brauer K, Hartig W, Wolff JR, Rickmann MJ, Derouiche A, Delpech B, Girard N, Oertel WH, Reichenbach A (1993) Perineuronal nets provide a polyanionic, glia-associated form of microenvironment around certain neurons in many parts of the rat brain. Glia 8:183-200

Bruckner G, Grosche J, Schmidt S, Hartig W, Margolis RU, Delpech B, Seidenbecher CI, Czaniera R, Schachner M (2000) Postnatal development of perineuronal nets in wild-type mice and in a mutant deficient in tenascin-R. J Comp Neurol 428:616-629

Bruckner G, Szeoke S, Pavlica S, Grosche J, Kacza J (2006) Axon initial segment ensheathed by extracellular matrix in perineuronal nets. Neuroscience 138:365-375

Bulow HE, Hobert O (2006) The molecular diversity of glycosaminoglycans shapes animal development. Annu Rev Cell Dev Biol 22:375-407

Camenisch TD, Spicer AP, Brehm-Gibson T, Biesterfeldt J, Augustine ML, Calabro A Jr, Kubalak S, Klewer SE, McDonald JA (2000) Disruption of hyaluronan synthase-2 abrogates normal cardiac morphogenesis and hyaluronan-mediated transformation of epithelium to mesenchyme. J Clin Invest 106:349-360

Carbonetto S (1984) The extracellular matrix of the nervous system. Trends Neurosci 7:382-387

Carulli D, Rhodes KE, Brown DJ, Bonnert TP, Pollack SJ, Oliver K, Strata P, Fawcett JW (2006) Composition of perineuronal nets in the adult rat cerebellum and the cellular origin of their components. J Comp Neurol 494:559-577

Carulli D, Rhodes KE, Fawcett JW (2007) Upregulation of aggrecan, link protein 1, and hyaluronan synthases during formation of perineuronal nets in the rat cerebellum. J Comp Neurol 501:83-94

Caterson B, Flannery CR, Hughes CE, Little CB (2000) Mechanisms involved in cartilage proteoglycan catabolism. Matrix Biol 19:333-344

Celio MR, Blumcke I (1994) Perineuronal nets-a specialized form of extracellular matrix in the adult nervous system. Brain Res Brain Res Rev 19:128-145

Celio MR, Spreafico R, De Biasi S, Vitellaro-Zuccarello L (1998) Perineuronal nets: past and present. Trends Neurosci 21:510-515

Chiquet-Ehrismann R, Chiquet M (2003) Tenascins: regulation and putative functions during pathological stress. J Pathol 200:488499

Christopherson KS, Ullian EM, Stokes CC, Mullowney CE, Hell JW, Agah A, Lawler J, Mosher DF, Bornstein P, Barres BA (2005)
Thrombospondins are astrocyte-secreted proteins that promote CNS synaptogenesis. Cell 120:421-433

Collins-Racie LA, Flannery CR, Zeng W, Corcoran C, Annis-Freeman B, Agostino MJ, Arai M, DiBlasio-Smith E, Dorner AJ, Georgiadis KE, Jin M, Tan XY, Morris EA, LaVallie ER (2004) ADAMTS- 8 exhibits aggrecanase activity and is expressed in human articular cartilage. Matrix Biol 23:219-230

Cross AK, Haddock G, Stock CJ, Allan S, Surr J, Bunning RA, Buttle DJ, Woodroofe MN (2006) ADAMTS-1 and -4 are up-regulated following transient middle cerebral artery occlusion in the rat and their expression is modulated by TNF in cultured astrocytes. Brain Res 1088:19-30

Crossin KL, Hoffman S, Grumet M, Thiery JP, Edelman GM (1986) Site-restricted expression of cytotactin during development of the chicken embryo. J Cell Biol 102:1917-1930

Day AJ, Prestwich GD (2002) Hyaluronan-binding proteins: tying up the giant. J Biol Chem 277:4585-4588

DeAngelis PL (1999) Hyaluronan synthases: fascinating glycosyltransferases from vertebrates, bacterial pathogens, and algal viruses. Cell Mol Life Sci 56:670-682

Deepa SS, Carulli D, Galtrey C, Rhodes K, Fukuda J, Mikami T, Sugahara K, Fawcett JW (2006) Composition of perineuronal net extracellular matrix in rat brain: a different disaccharide composition for the net-associated proteoglycans. J Biol Chem 281:17789-17800

Delpech B, Halavent C (1981) Characterization and purification from human brain of a hyaluronic acid-binding glycoprotein, hyaluronectin. J Neurochem 36:855-859

Deyst KA, Toole BP (1995) Production of hyaluronan-dependent pericellular matrix by embryonic rat glial cells. Brain Res Dev Brain Res 88:122-125

Domowicz MS, Sanders TA, Ragsdale CW, Schwartz NB (2008) Aggrecan is expressed by embryonic brain glia and regulates astrocyte development. Dev Biol 315:114-124

Dorries U, Schachner M (1994) Tenascin mRNA isoforms in the developing mouse brain. J Neurosci Res 37:336-347

Dours-Zimmermann MT, Zimmermann DR (1994) A novel glycosaminoglycan attachment domain identified in two alternative splice variants of human versican. J Biol Chem 269:32992-32998

Dutt S, Kleber M, Matasci M, Sommer L, Zimmermann DR (2006) Versican V0 and V1 guide migratory neural crest cells. J Biol Chem 281:12123-12131

Engel M, Maurel P, Margolis RU, Margolis RK (1996) Chondroitin sulfate proteoglycans in the developing central nervous system. I. cellular sites of synthesis of neurocan and phosphacan. J Comp Neurol 366:34-43

Ethell IM, Ethell DW (2007) Matrix metalloproteinases in brain development and remodeling: synaptic functions and targets. J Neurosci Res 85:2813-2823

Evanko SP, Tammi MI, Tammi RH, Wight TN (2007) Hyaluronandependent pericellular matrix. Adv Drug Deliv Rev 59:13511365

Evers MR, Salmen B, Bukalo O, Rollenhagen A, Bosl MR, Morellini F, Bartsch U, Dityatev A, Schachner M (2002) Impairment of Ltype $\mathrm{Ca} 2+$ channel-dependent forms of hippocampal synaptic plasticity in mice deficient in the extracellular matrix glycoprotein tenascin-C. J Neurosci 22:7177-7194

Flannery CR (2006) MMPs and ADAMTSs: functional studies. Front Biosci 11:544-569

Forsberg E, Hirsch E, Fröhlich L, Meyer M, Ekblom P, Aszodi A, Werner S, Fässler R (1996) Skin wounds and severed nerves heal normally in mice lacking tenascin-C. Proc Natl Acad Sci USA 93:6594-6599

Freitag S, Schachner M, Morellini F (2003) Behavioral alterations in mice deficient for the extracellular matrix glycoprotein tenascinR. Behav Brain Res 145:189-207 
Fukamauchi F, Mataga N, Wang YJ, Sato S, Youshiki A, Kusakabe M (1996) Abnormal behavior and neurotransmissions of tenascin gene knockout mouse. Biochem Biophys Res Commun 221:151-156

Fuss B, Wintergerst ES, Bartsch U, Schachner M (1993) Molecular characterization and in situ mRNA localization of the neural recognition molecule J1-160/180: a modular structure similar to tenascin. J Cell Biol 120:1237-1249

Galtrey CM, Fawcett JW (2007) The role of chondroitin sulfate proteoglycans in regeneration and plasticity in the central nervous system. Brain Res Rev 54:1-18

Galtrey CM, Kwok JC, Carulli D, Rhodes KE, Fawcett JW (2008) Distribution and synthesis of extracellular matrix proteoglycans, hyaluronan, link proteins and tenascin- $\mathrm{R}$ in the rat spinal cord. Eur $\mathrm{J}$ Neurosci 27:1373-1390

Gao G, Westling J, Thompson VP, Howell TD, Gottschall PE, Sandy JD (2002) Activation of the proteolytic activity of ADAMTS4 (aggrecanase-1) by C-terminal truncation. J Biol Chem 277:11034-11041

Gates MA, Thomas LB, Howard EM, Laywell ED, Sajin B, Faissner A, Gotz B, Silver J, Steindler DA (1995) Cell and molecular analysis of the developing and adult mouse subventricular zone of the cerebral hemispheres. J Comp Neurol 361:249-266

Gonzenbach RR, Schwab ME (2008) Disinhibition of neurite growth to repair the injured adult CNS: Focusing on Nogo. Cell Mol Life Sci 65:161-176

Gottschall PE, Sandy JD, Zimmermann DR (2005) Substrates for metalloendopeptidases in the central nervous system. In: Conant $\mathrm{K}$, Gottschall PE (eds) Matrix metalloproteinases in the central nervous system. Imperial College Press, London, pp 87-118

Guimaraes A, Zaremba S, Hockfield S (1990) Molecular and morphological changes in the cat lateral geniculate nucleus and visual cortex induced by visual deprivation are revealed by monoclonal antibodies Cat-304 and Cat-301. J Neurosci 10:3014-3024

Gunther W, Skaftnesmo KO, Arnold H, Bjerkvig R, Terzis AJ (2005) Distribution patterns of the anti-angiogenic protein ADAMTS-1 during rat development. Acta Histochem 107:121-131

Haas CA, Rauch U, Thon N, Merten T, Deller T (1999) Entorhinal cortex lesion in adult rats induces the expression of the neuronal chondroitin sulfate proteoglycan neurocan in reactive astrocytes. J Neurosci 19:9953-9963

Harroch S, Palmeri M, Rosenbluth J, Custer A, Okigaki M, Shrager P, Blum M, Buxbaum JD, Schlessinger J (2000) No obvious abnormality in mice deficient in receptor protein tyrosine phosphatase beta. Mol Cell Biol 20:7706-7715

Harroch S, Furtado GC, Brueck W, Rosenbluth J, Lafaille J, Chao M, Buxbaum JD, Schlessinger J (2002) A critical role for the protein tyrosine phosphatase receptor type $\mathrm{Z}$ in functional recovery from demyelinating lesions. Nat Genet 32:411-414

Haunso A, Celio MR, Margolis RK, Menoud PA (1999) Phosphacan immunoreactivity is associated with perineuronal nets around parvalbumin-expressing neurones. Brain Res 834:219-222

Haunso A, Ibrahim M, Bartsch U, Letiembre M, Celio MR, Menoud P (2000) Morphology of perineuronal nets in tenascin-R and parvalbumin single and double knockout mice. Brain Res 864:142-145

Hedstrom KL, Rasband MN (2006) Intrinsic and extrinsic determinants of ion channel localization in neurons. J Neurochem 98:1345-1352

Hedstrom KL, Xu X, Ogawa Y, Frischknecht R, Seidenbecher CI, Shrager P, Rasband MN (2007) Neurofascin assembles a specialized extracellular matrix at the axon initial segment. J Cell Biol 178:875-886

Held-Feindt J, Paredes EB, Blomer U, Seidenbecher C, Stark AM, Mehdorn HM, Mentlein R (2006) Matrix-degrading proteases ADAMTS4 and ADAMTS5 (disintegrins and metalloproteinases with thrombospondin motifs 4 and 5) are expressed in human glioblastomas. Int J Cancer 118:55-61
Herz J, Chen Y (2006) Reelin, lipoprotein receptors and synaptic plasticity. Nat Rev Neurosci 7:850-859

Hirakawa S, Oohashi T, Su WD, Yoshioka H, Murakami T, Arata J, Ninomiya Y (2000) The brain link protein-1 (BRAL1): cDNA cloning, genomic structure, and characterization as a novel link protein expressed in adult brain. Biochem Biophys Res Commun 276:982-989

Hockfield S, Kalb RG, Zaremba S, Fryer H (1990) Expression of neural proteoglycans correlates with the acquisition of mature neuronal properties in the mammalian brain. Cold Spring Harb Symp Quant Biol 55:505-514

Hooks BM, Chen C (2007) Critical periods in the visual system: changing views for a model of experience-dependent plasticity. Neuron 56:312-326

Hsia HC, Schwarzbauer JE (2005) Meet the tenascins: multifunctional and mysterious. J Biol Chem 280:26641-26644

Ikuta T, Sogawa N, Ariga H, Ikemura T, Matsumoto K (1998) Structural analysis of mouse tenascin-X: evolutionary aspects of reduplication of FNIII repeats in the tenascin gene family. Gene 217:1-13

Iozzo RV, Murdoch AD (1996) Proteoglycans of the extracellular environment-clues from the gene and protein side offer novel perspectives in molecular diversity and function (review). FASEB J 10:598-614

Isogai Z, Aspberg A, Keene DR, Ono RN, Reinhardt DP, Sakai LY (2002) Versican interacts with fibrillin-1 and links extracellular microfibrils to other connective tissue networks. J Biol Chem 277:4565-4572

Itano N, Kimata K (2002) Mammalian hyaluronan synthases. IUBMB Life 54:195-199

Joester A, Faissner A (1999) Evidence for combinatorial variability of tenascin- $\mathrm{C}$ isoforms and developmental regulation in the mouse central nervous system. J Biol Chem 274:17144-17151

Joester A, Faissner A (2001) The structure and function of tenascins in the nervous system. Matrix Biol 20:13-22

John N, Krugel H, Frischknecht R, Smalla KH, Schultz C, Kreutz MR, Gundelfinger ED, Seidenbecher CI (2006) Brevican-containing perineuronal nets of extracellular matrix in dissociated hippocampal primary cultures. Mol Cell Neurosci 31:774-784

Jones FS, Jones PL (2000) The tenascin family of ECM glycoproteins: structure, function, and regulation during embryonic development and tissue remodeling. Dev Dyn 218:235-259

Jones LL, Margolis RU, Tuszynski MH (2003) The chondroitin sulfate proteoglycans neurocan, brevican, phosphacan, and versican are differentially regulated following spinal cord injury. Exp Neurol 182:399-411

Jonsson-Rylander AC, Nilsson T, Fritsche-Danielson R, Hammarstrom A, Behrendt M, Andersson JO, Lindgren K, Andersson AK, Wallbrandt P, Rosengren B, Brodin P, Thelin A, Westin A, HurtCamejo E, Lee-Sogaard CH (2005) Role of ADAMTS-1 in atherosclerosis: remodeling of carotid artery, immunohistochemistry, and proteolysis of versican. Arterioscler Thromb Vasc Biol 25:180-185

Jungers KA, Le Goff C, Somerville RP, Apte SS (2005) Adamts9 is widely expressed during mouse embryo development. Gene Expr Patterns 5:609-617

Kalb RG, Hockfield S (1988) Molecular evidence for early activitydependent development of hamster motor neurons. J Neurosci 8:2350-2360

Kalb RG, Hockfield S (1990) Large diameter primary afferent input is required for expression of the Cat-301 proteoglycan on the surface of motor neurons. Neuroscience 34:391-401

Kiernan BW, Garcion E, Ferguson J, Frost EE, Torres EM, Dunnett SB, Saga Y, Aizawa S, Faissner A, Kaur R, Franklin RJ, ffrenchConstant C (1999) Myelination and behaviour of tenascin-C null transgenic mice. Eur J Neurosci 11:3082-3092 
Kjellén L, Lindahl U (1991) Proteoglycans: structures, interactions (published erratum appears in Annu Rev Biochem (1992) 61, following viii). Annu Rev Biochem 60:443-475

Kultti A, Rilla K, Tiihonen R, Spicer AP, Tammi RH, Tammi MI (2006) Hyaluronan synthesis induces microvillus-like cell surface protrusions. J Biol Chem 281:15821-15828

Kuno K, Okada Y, Kawashima H, Nakamura H, Miyasaka M, Ohno H, Matsushima K (2000) ADAMTS-1 cleaves a cartilage proteoglycan, aggrecan. FEBS Lett 478:241-245

Kusche-Gullberg M, Kjellen L (2003) Sulfotransferases in glycosaminoglycan biosynthesis. Curr Opin Struct Biol 13:605-611

Lander C, Kind P, Maleski M, Hockfield S (1997) A family of activitydependent neuronal cell-surface chondroitin sulfate proteoglycans in cat visual cortex. J Neurosci 17:1928-1939

Landolt RM, Vaughan L, Winterhalter KH, Zimmermann DR (1995) Versican is selectively expressed in embryonic tissues that act as barriers to neural crest cell migration and axon outgrowth. Development 121:2303-2312

Laywell ED, Steindler DA (1991) Boundaries and wounds, glia and glycoconjugates. Cellular and molecular analyses of developmental partitions and adult brain lesions. Ann NY Acad Sci 633:122141

Laywell ED, Dorries U, Bartsch U, Faissner A, Schachner M, Steindler DA (1992) Enhanced expression of the developmentally regulated extracellular matrix molecule tenascin following adult brain injury. Proc Natl Acad Sci USA 89:2634-2638

LeBaron RG, Zimmermann DR, Ruoslahti E (1992) Hyaluronate binding properties of versican. J Biol Chem 267:10003-10010

Lein ES, Hawrylycz MJ, Ao N, Ayres M, Bensinger A, Bernard A, Boe AF, Boguski MS, Brockway KS, Byrnes EJ, Chen L, Chen L, Chen TM, Chin MC, Chong J, Crook BE, Czaplinska A, Dang CN, Datta S, Dee NR, Desaki AL, Desta T, Diep E, Dolbeare TA, Donelan MJ, Dong HW, Dougherty JG, Duncan BJ, Ebbert AJ, Eichele G, Estin LK, Faber C, Facer BA, Fields R, Fischer SR, Fliss TP, Frensley C, Gates SN, Glattfelder KJ, Halverson KR, Hart MR, Hohmann JG, Howell MP, Jeung DP, Johnson RA, Karr PT, Kawal R, Kidney JM, Knapik RH, Kuan CL, Lake JH, Laramee AR, Larsen KD, Lau C, Lemon TA, Liang AJ, Liu Y, Luong LT, Michaels J, Morgan JJ, Morgan RJ, Mortrud MT, Mosqueda NF, Ng LL, Ng R, Orta GJ, Overly CC, Pak TH, Parry SE, Pathak SD, Pearson OC, Puchalski RB, Riley ZL, Rockett HR, Rowland SA, Royall JJ, Ruiz MJ, Sarno NR, Schaffnit K, Shapovalova NV, Sivisay T, Slaughterbeck CR, Smith SC, Smith KA, Smith BI, Sodt AJ, Stewart NN, Stumpf KR, Sunkin SM, Sutram M, Tam A, Teemer CD, Thaller C, Thompson CL, Varnam LR, Visel A, Whitlock RM, Wohnoutka PE, Wolkey CK, Wong VY, Wood M, Yaylaoglu MB, Young RC, Youngstrom BL, Yuan XF, Zhang B, Zwingman TA, Jones AR (2007) Genome-wide atlas of gene expression in the adult mouse brain. Nature 445:168-176

Lemons ML, Sandy JD, Anderson DK, Howland DR (2001) Intact aggrecan and fragments generated by both aggrecanse and metalloproteinase-like activities are present in the developing and adult rat spinal cord and their relative abundance is altered by injury. J Neurosci 21:4772-4781

Lundell A, Olin AI, Morgelin M, al-Karadaghi S, Aspberg A, Logan DT (2004) Structural basis for interactions between tenascins and lectican C-type lectin domains: evidence for a crosslinking role for tenascins. Structure 12:1495-1506

Maeda N, Noda M (1996) 6B4 proteoglycan/phosphacan is a repulsive substratum but promotes morphological differentiation of cortical neurons. Development 122:647-658

Maeda N, Hamanaka H, Oohira A, Noda M (1995) Purification, characterization and developmental expression of a brain-specific chondroitin sulfate proteoglycan, 6B4 proteoglycan/phosphacan. Neuroscience 67:23-35
Margolis RK, Margolis RU, Preti C, Lai D (1975) Distribution and metabolism of glycoproteins and glycosaminoglycans in subcellular fractions of brain. Biochemistry 14:4797-4804

Margolis RK, Rauch U, Maurel P, Margolis RU (1996) Neurocan and phosphacan-two major nervous tissue-specific chondroitin sulfate proteoglycans. Perspect Dev Neurobiol 3:273-290

Matsui F, Kawashima S, Shuo T, Yamauchi S, Tokita Y, Aono S, Keino H, Oohira A (2002) Transient expression of juvenile-type neurocan by reactive astrocytes in adult rat brains injured by kainate-induced seizures as well as surgical incision. Neuroscience 112:773-781

Matsumoto K, Saga Y, Ikemura T, Sakakura T, Chiquet-Ehrismann R (1994) The distribution of tenascin-X is distinct and often reciprocal to that of tenascin-C. J Cell Biol 125:483-493

Matsumoto K, Shionyu M, Go M, Shimizu K, Shinomura T, Kimata K, Watanabe H (2003) Distinct interaction of versican/PG-M with hyaluronan and link protein. J Biol Chem 278:41205-41212

Matthews RT, Gary SC, Zerillo C, Pratta M, Solomon K, Arner EC, Hockfield S (2000) Brain-enriched hyaluronan binding (BE$\mathrm{HAB}$ )/brevican cleavage in a glioma cell line is mediated by a disintegrin and metalloproteinase with thrombospondin motifs (ADAMTS) family member. J Biol Chem 275:22695-22703

Matthews RT, Kelly GM, Zerillo CA, Gray G, Tiemeyer M, Hockfield S (2002) Aggrecan glycoforms contribute to the molecular heterogeneity of perineuronal nets. J Neurosci 22:7536-7547

Maurel P, Rauch U, Flad M, Margolis RK, Margolis RU (1994) Phosphacan, a chondroitin sulfate proteoglycan of brain that interacts with neurons and neural cell-adhesion molecules, is an extracellular variant of a receptor-type protein tyrosine phosphatase. Proc Natl Acad Sci USA 91:2512-2516

Mayer J, Hamel MG, Gottschall PE (2005) Evidence for proteolytic cleavage of brevican by the ADAMTSs in the dentate gyrus after excitotoxic lesion of the mouse entorhinal cortex. BMC Neurosci 6:52

McKeon RJ, Jurynec MJ, Buck CR (1999) The chondroitin sulfate proteoglycans neurocan and phosphacan are expressed by reactive astrocytes in the chronic CNS glial scar. J Neurosci 19:1077810788

Melendez-Vasquez C, Carey DJ, Zanazzi G, Reizes O, Maurel P, Salzer JL (2005) Differential expression of proteoglycans at central and peripheral nodes of Ranvier. Glia 52:301-308

Meyer-Puttlitz B, Milev P, Junker E, Zimmer I, Margolis RU, Margolis RK (1995) Chondroitin sulfate and chondroitin/keratan sulfate proteoglycans of nervous tissue: developmental changes of neurocan and phosphacan. J Neurochem 65:2327-2337

Meyer-Puttlitz B, Junker E, Margolis RU, Margolis RK (1996) Chondroitin sulfate proteoglycans in the developing central nervous system. II. Immunocytochemical localization of neurocan and phosphacan. J Comp Neurol 366:44-54

Miguel RF, Pollak A, Lubec G (2005) Metalloproteinase ADAMTS-1 but not ADAMTS-5 is manifold overexpressed in neurodegenerative disorders as Down syndrome, Alzheimer's and Pick's disease. Brain Res Mol Brain Res 133:1-5

Milev P, Friedlander DR, Sakurai T, Karthikeyan L, Flad M, Margolis RK, Grumet M, Margolis RU (1994) Interactions of the chondroitin sulfate proteoglycan phosphacan, the extracellular domain of a receptor-type protein tyrosine phosphatase, with neurons, glia, and neural cell adhesion molecules. J Cell Biol 127:1703-1715

Milev P, Maurel P, Haring M, Margolis RK, Margolis RU (1996) TAG-1/axonin-1 is a high-affinity ligand of neurocan, phosphacan/protein-tyrosine phosphatase-zeta/beta, and N-CAM. J Biol Chem 271:15716-15723

Milev P, Fischer D, Haring M, Schulthess T, Margolis RK, ChiquetEhrismann R, Margolis RU (1997) The fibrinogen-like globe of tenascin- $\mathrm{C}$ mediates its interactions with neurocan and phosph- 
acan/protein-tyrosine phosphatase-zeta/beta. J Biol Chem 272:15501-15509

Milev P, Chiba A, Haring M, Rauvala H, Schachner M, Ranscht B, Margolis RK, Margolis RU (1998a) High affinity binding and overlapping localization of neurocan and phosphacan proteintyrosine phosphatase-zeta/beta with tenascin-R, amphoterin, and the heparin-binding growth-associated molecule. J Biol Chem 273:6998-7005

Milev P, Maurel P, Chiba A, Mevissen M, Popp S, Yamaguchi Y, Margolis RK, Margolis RU (1998b) Differential regulation of expression of hyaluronan-binding proteoglycans in developing brain: aggrecan, versican, neurocan, and brevican. Biochem Biophys Res Commun 247:207-212

Milev P, Monnerie H, Popp S, Margolis RK, Margolis RU (1998c) The core protein of the chondroitin sulfate proteoglycan phosphacan is a high-affinity ligand of fibroblast growth factor- 2 and potentiates its mitogenic activity. J Biol Chem 273:21439-21442

Miller B, Sheppard AM, Bicknese AR, Pearlman AL (1995) Chondroitin sulfate proteoglycans in the developing cerebral cortex: the distribution of neurocan distinguishes forming afferent and efferent axonal pathways. J Comp Neurol 355:615-628

Milward EA, Fitzsimmons C, Szklarczyk A, Conant K (2007) The matrix metalloproteinases and CNS plasticity: an overview. J Neuroimmunol 187:9-19

Miura R, Aspberg A, Ethell IM, Hagihara K, Schnaar RL, Ruoslahti E, Yamaguchi Y (1999) The proteoglycan lectin domain binds sulfated cell surface glycolipids and promotes cell adhesion. J Biol Chem 274:11431-11438

Miyata S, Nishimura Y, Hayashi N, Oohira A (2005) Construction of perineuronal net-like structure by cortical neurons in culture. Neuroscience 136:95-104

Miyata S, Nishimura Y, Nakashima T (2007) Perineuronal nets protect against amyloid beta-protein neurotoxicity in cultured cortical neurons. Brain Res 1150:200-206

Mjaatvedt C, Yamamura H, Capehart A, Turner D, Markwald R (1998) The cspg2 gene, disrupted in the $h d f$ mutant, is required for right cardiac chamber and endocardial cushion formation. Dev Biol 202:56-66

Montag-Sallaz M, Montag D (2003) Severe cognitive and motor coordination deficits in tenascin-R-deficient mice. Genes Brain Behav 2:20-31

Moon LD, Asher RA, Rhodes KE, Fawcett JW (2001) Regeneration of CNS axons back to their target following treatment of adult rat brain with chondroitinase ABC. Nat Neurosci 4:465-466

Morawski M, Bruckner MK, Riederer P, Bruckner G, Arendt T (2004) Perineuronal nets potentially protect against oxidative stress. Exp Neurol 188:309-315

Morgenstern DA, Asher RA, Fawcett JW (2002) Chondroitin sulphate proteoglycans in the CNS injury response. Prog Brain Res 137:313-332

Murakami T, Ohtsuka A (2003) Perisynaptic barrier of proteoglycans in the mature brain and spinal cord. Arch Histol Cytol 66:195-207

Mörgelin M, Paulsson M, Malmström A, Heinegård D (1989) Shared and distinct structural features of interstitial proteoglycans from different bovine tissues revealed by electron microscopy. J Biol Chem 264:12080-12090

Nakada M, Miyamori H, Kita D, Takahashi T, Yamashita J, Sato H, Miura R, Yamaguchi Y, Okada Y (2005) Human glioblastomas overexpress ADAMTS-5 that degrades brevican. Acta Neuropathol 110:239-246

Nakamura H, Fujii Y, Inoki I, Sugimoto K, Tanzawa K, Matsuki H, Miura R, Yamaguchi Y, Okada Y (2000) Brevican is degraded by matrix metalloproteinases and aggrecanase-1 (ADAMTS4) at different sites. J Biol Chem 275:38885-38890

Neame PJ, Barry FP (1993) The link proteins. Experientia 49:393-402
Neame PJ, Christner JE, Baker JR (1987) Cartilage proteoglycan aggregates. The link protein and proteoglycan amino-terminal globular domains have similar structures. J Biol Chem 262:17768-17778

Neidhardt J, Fehr S, Kutsche M, Lohler J, Schachner M (2003) Tenascin-N: characterization of a novel member of the tenascin family that mediates neurite repulsion from hippocampal explants. Mol Cell Neurosci 23:193-209

Nicholson C, Sykova E (1998) Extracellular space structure revealed by diffusion analysis. Trends Neurosci 21:207-215

Niederöst BP, Zimmermann DR, Schwab ME, Bandtlow CE (1999) Bovine CNS myelin contains neurite growth inhibitory activity associated with chondroitin sulfate proteoglycans. J Neurosci 19:8979-8989

Niisato K, Fujikawa A, Komai S, Shintani T, Watanabe E, Sakaguchi G, Katsuura G, Manabe T, Noda M (2005) Age-dependent enhancement of hippocampal long-term potentiation and impairment of spatial learning through the Rho-associated kinase pathway in protein tyrosine phosphatase receptor type Z-deficient mice. J Neurosci 25:1081-1088

Novak U, Kaye AH (2000) Extracellular matrix and the brain: components and function. J Clin Neurosci 7:280-290

Nutt CL, Matthews RT, Hockfield S (2001) Glial tumor invasion: a role for the upregulation and cleavage of BEHAB/brevican. Neuroscientist 7:113-122

Oakley RA, Tosney KW (1991) Peanut agglutinin and chondroitin-6sulfate are molecular markers for tissues that act as barriers to axon advance in the avian embryo. Dev Biol 147:187-206

Ogawa T, Hagihara K, Suzuki M, Yamaguchi Y (2001) Brevican in the developing hippocampal fimbria: differential expression in myelinating oligodendrocytes and adult astrocytes suggests a dual role for brevican in central nervous system fiber tract development. J Comp Neurol 432:285-295

Ogawa H, Oohashi T, Sata M, Bekku Y, Hirohata S, Nakamura K, Yonezawa T, Kusachi S, Shiratori Y, Ninomiya Y (2004) Lp3/Hap$\ln 3$, a novel link protein that co-localizes with versican and is coordinately up-regulated by platelet-derived growth factor in arterial smooth muscle cells. Matrix Biol 23:287-298

Olin AI, Morgelin M, Sasaki T, Timpl R, Heinegard D, Aspberg A (2001) The proteoglycans aggrecan and Versican form networks with fibulin- 2 through their lectin domain binding. J Biol Chem 276:1253-1261

Oohashi T, Hirakawa S, Bekku Y, Rauch U, Zimmermann DR, Su WD, Ohtsuka A, Murakami T, Ninomiya Y (2002) Bral1, a brainspecific link protein, colocalizing with the versican V2 isoform at the nodes of Ranvier in developing and adult mouse central nervous systems. Mol Cell Neurosci 19:43-57

Peles E, Nativ M, Campbell PL, Sakurai T, Martinez R, Lev S, Clary DO, Schilling J, Barnea G, Plowman GD, Grumet M, Schlessinger J (1995) The carbonic anhydrase domain of receptor tyrosine phosphatase beta is a functional ligand for the axonal cell recognition molecule contactin. Cell 82:251-260

Perides G, Lane WS, Andrews D, Dahl D, Bignami A (1989) Isolation and partial characterization of a glial hyaluronate-binding protein. J Biol Chem 264:5981-5987

Perides G, Erickson HP, Rahemtulla F, Bignami A (1993) Colocalization of tenascin with versican, a hyaluronate-binding chondroitin sulfate proteoglycan. Anat Embryol Berl 188:467-479

Pesheva P, Spiess E, Schachner M (1989) J1-160 and J1-180 are oligodendrocyte-secreted nonpermissive substrates for cell adhesion. J Cell Biol 109:1765-1778

Pindzola RR, Doller C, Silver J (1993) Putative inhibitory extracellular matrix molecules at the dorsal root entry zone of the spinal cord during development and after root and sciatic nerve lesions. Dev Biol 156:34-48 
Pizzorusso T, Medini P, Berardi N, Chierzi S, Fawcett JW, Maffei L (2002) Reactivation of ocular dominance plasticity in the adult visual cortex. Science 298:1248-1251

Pizzorusso T, Medini P, Landi S, Baldini S, Berardi N, Maffei L (2006) Structural and functional recovery from early monocular deprivation in adult rats. Proc Natl Acad Sci USA 103:8517-8522

Poliak S, Peles E (2003) The local differentiation of myelinated axons at nodes of Ranvier. Nat Rev Neurosci 4:968-980

Popp S, Andersen JS, Maurel P, Margolis RU (2003) Localization of aggrecan and versican in the developing rat central nervous system. Dev Dyn 227:143-149

Porter S, Clark IM, Kevorkian L, Edwards DR (2005) The ADAMTS metalloproteinases. Biochem J 386:15-27

Prieto AL, Jones FS, Cunningham BA, Crossin KL, Edelman GM (1990) Localization during development of alternatively spliced forms of cytotactin mRNA by in situ hybridization. J Cell Biol 111:685-698

Prydz K, Dalen KT (2000) Synthesis and sorting of proteoglycans. J Cell Sci 113(Pt 2):193-205

Quaglia X, Beggah AT, Seidenbecher C, Zurn AD (2008) Delayed priming promotes CNS regeneration post-rhizotomy in neurocan and brevican-deficient mice. Brain 131:240-249

Ratcliffe CF, Qu Y, McCormick KA, Tibbs VC, Dixon JE, Scheuer T, Catterall WA (2000) A sodium channel signaling complex: modulation by associated receptor protein tyrosine phosphatase beta. Nat Neurosci 3:437-444

Rauch U (1997) Modeling an extracellular environment for axonal pathfinding and fasciculation in the central nervous system. Cell Tissue Res 290:349-356

Rauch U (2004) Extracellular matrix components associated with remodeling processes in brain. Cell Mol Life Sci 61:2031-2045

Rauch U, Gao P, Janetzko A, Flaccus A, Hilgenberg L, Tekotte H, Margolis RK, Margolis RU (1991) Isolation and characterization of developmentally regulated chondroitin sulfate and chondroitin/ keratan sulfate proteoglycans of brain identified with monoclonal antibodies. J Biol Chem 266:14785-14801

Rauch U, Clement A, Retzler C, Fröhlich L, Fässler R, Göhring W, Faissner A (1997) Mapping of a defined neurocan binding site to distinct domains of tenascin-C. J Biol Chem 272:26905-26912

Rauch U, Hirakawa S, Oohashi T, Kappler J, Roos G (2004) Cartilage link protein interacts with neurocan, which shows hyaluronan binding characteristics different from CD44 and TSG-6. Matrix Biol 22:629-639

Rauch U, Zhou XH, Roos G (2005) Extracellular matrix alterations in brains lacking four of its components. Biochem Biophys Res Commun 328:608-617

Retzler C, Wiedemann H, Kulbe G, Rauch U (1996) Structural and electron microscopic analysis of neurocan and recombinant neurocan fragments. J Biol Chem 271:17107-17113

Rhodes KE, Fawcett JW (2004) Chondroitin sulphate proteoglycans: preventing plasticity or protecting the CNS? J Anat 204:33-48

Rilla K, Tiihonen R, Kultti A, Tammi M, Tammi R (2008) Pericellular hyaluronan coat visualized in live cells with a fluorescent probe is scaffolded by plasma membrane protrusions. J Histochem Cytochem (in press)

Ripellino JA, Bailo M, Margolis RU, Margolis RK (1988) Light and electron microscopic studies on the localization of hyaluronic acid in developing rat cerebellum. J Cell Biol 106:845-855

Rodriguez-Manzaneque JC, Milchanowski AB, Dufour EK, Leduc R, Iruela-Arispe ML (2000) Characterization of METH-1/ADAMTS1 processing reveals two distinct active forms. J Biol Chem 275:33471-33479

Ruoslahti E (1996) Brain extracellular matrix (review). Glycobiology 6:489-492

Rutka JT, Apodaca G, Stern R, Rosenblum M (1988) The extracellular matrix of the central and peripheral nervous systems: structure and function. J Neurosurg 69:155-170
Saga Y, Yagi T, Ikawa Y, Sakakura T, Aizawa S (1992) Mice develop normally without tenascin. Genes Dev 6:1821-1831

Saghatelyan A, de Chevigny A, Schachner M, Lledo PM (2004) Tenascin-R mediates activity-dependent recruitment of neuroblasts in the adult mouse forebrain. Nat Neurosci 7:347-356

Salzer JL (2003) Polarized domains of myelinated axons. Neuron 40:297-318

Sandy JD, Westling J, Kenagy RD, Iruela-Arispe ML, Verscharen C, Rodriguez-Mazaneque JC, Zimmermann DR, Lemire JM, Fischer JW, Wight TN, Clowes AW (2001) Versican V1 proteolysis in human aorta in vivo occurs at the Glu441-Ala442 bond, a site that is cleaved by recombinant ADAMTS-1 and ADAMTS-4. J Biol Chem 276:13372-13378

Sanes JR (1989) Extracellular matrix molecules that influence neural development. Annu Rev Neurosci 12:491-516

Sasaki M, Seo-Kiryu S, Kato R, Kita S, Kiyama H (2001) A disintegrin and metalloprotease with thrombospondin type1 motifs (ADAMTS-1) and IL-1 receptor type 1 mRNAs are simultaneously induced in nerve injured motor neurons. Brain Res Mol Brain Res $89: 158-163$

Satoh K, Suzuki N, Yokota H (2000) ADAMTS-4 (a disintegrin and metalloproteinase with thrombospondin motifs) is transcriptionally induced in beta-amyloid treated rat astrocytes. Neurosci Lett 289:177-180

Scherberich A, Tucker RP, Samandari E, Brown-Luedi M, Martin D, Chiquet-Ehrismann R (2004) Murine tenascin-W: a novel mammalian tenascin expressed in kidney and at sites of bone and smooth muscle development. J Cell Sci 117:571-581

Schmalfeldt M, Dours-Zimmermann MT, Winterhalter KH, Zimmermann DR (1998) Versican V2 is a major extracellular matrix component of the mature bovine brain. J Biol Chem 273:15758-15764

Schmalfeldt M, Bandtlow CE, Dours-Zimmermann MT, Winterhalter KH, Zimmermann DR (2000) Brain derived versican V2 is a potent inhibitor of axonal growth. J Cell Sci 113:807-816

Schwartz NB, Domowicz M (2004) Proteoglycans in brain development. Glycoconj J 21:329-341

Seidenbecher CI, Richter K, Rauch U, Fässler R, Garner CC, Gundelfinger ED (1995) Brevican, a chondroitin sulfate proteoglycan of rat brain, occurs as secreted and cell surface glycosylphosphatidylinositol-anchored isoforms. J Biol Chem 270:27206-27212

Seyfried NT, McVey GF, Almond A, Mahoney DJ, Dudhia J, Day AJ (2005) Expression and purification of functionally active hyaluronan-binding domains from human cartilage link protein, aggrecan and versican: formation of ternary complexes with defined hyaluronan oligosaccharides. J Biol Chem 280:5435-5448

Shi S, Grothe S, Zhang Y, O'Connor-McCourt MD, Poole AR, Roughley PJ, Mort JS (2004) Link protein has greater affinity for versican than aggrecan. J Biol Chem 279:12060-12066

Shitara K, Yamada H, Watanabe K, Shimonaka M, Yamaguchi Y (1994) Brain-specific receptor-type protein-tyrosine phosphatase RPTP beta is a chondroitin sulfate proteoglycan in vivo. J Biol Chem 269:20189-20193

Silver DL, Hou L, Somerville R, Young ME, Apte SS, Pavan WJ (2008) The secreted metalloprotease ADAMTS20 is required for melanoblast survival. PLoS Genet 4:e1000003

Snow DM, Lemmon V, Carrino DA, Caplan AI, Silver J (1990) Sulfated proteoglycans on astroglial barriers inhibit neurite outgrowth in vitro. Exp Neurol 109:111-130

Somerville RP, Longpre JM, Jungers KA, Engle JM, Ross M, Evanko S, Wight TN, Leduc R, Apte SS (2003) Characterization of ADAMTS-9 and ADAMTS-20 as a distinct ADAMTS subfamily related to Caenorhabditis elegans GON-1. J Biol Chem 278:95039513

Spicer AP, McDonald JA (1998) Characterization and molecular evolution of a vertebrate hyaluronan synthase gene family. J Biol Chem 273:1923-1932 
Spicer AP, Tien JY (2004) Hyaluronan and morphogenesis. Birth Defects Res C Embryo Today 72:89-108

Spicer AP, Joo A, Bowling RA Jr (2003) A hyaluronan binding link protein gene family whose members are physically linked adjacent to chondroitin sulfate proteoglycan core protein genes: the missing links. J Biol Chem 278:21083-21091

Steindler DA, Cooper NG, Faissner A, Schachner M (1989) Boundaries defined by adhesion molecules during development of the cerebral cortex: the $\mathrm{J} 1 /$ tenascin glycoprotein in the mouse somatosensory cortical barrel field. Dev Biol 131:243-260

Steindler DA, Settles D, Erickson HP, Laywell ED, Yoshiki A, Faissner A, Kusakabe M (1995) Tenascin knockout mice: barrels, boundary molecules, and glial scars. J Neurosci 15:1971-1983

Swindle CS, Tran KT, Johnson TD, Banerjee P, Mayes AM, Griffith L, Wells A (2001) Epidermal growth factor (EGF)-like repeats of human tenascin-C as ligands for EGF receptor. J Cell Biol 154:459-468

Tang BL (2003) Inhibitors of neuronal regeneration: mediators and signaling mechanisms. Neurochem Int 42:189-203

Tang X, Davies JE, Davies SJ (2003) Changes in distribution, cell associations, and protein expression levels of NG2, neurocan, phosphacan, brevican, versican V2, and tenascin-C during acute to chronic maturation of spinal cord scar tissue. J Neurosci Res 71:427-444

Tani E, Ametani T (1971) Extracellular distribution of ruthenium redpositive substance in the cerebral cortex. J Ultrastruct Res 34:1-14

Thai SN, Iruela-Arispe ML (2002) Expression of ADAMTS1 during murine development. Mech Dev 115:181-185

Thomas LB, Gates MA, Steindler DA (1996) Young neurons from the adult subependymal zone proliferate and migrate along an astrocyte, extracellular matrix-rich pathway. Glia 17:1-14

Tissir F, Goffinet AM (2003) Reelin and brain development. Nat Rev Neurosci 4:496-505

Toole BP (2000) Hyaluronan is not just a goo!. J Clin Invest 106:335-336

Toole BP (2001) Hyaluronan in morphogenesis. Semin Cell Dev Biol 12:79-87

Toole BP (2004) Hyaluronan: from extracellular glue to pericellular cue. Nat Rev Cancer 4:528-539

Tortorella MD, Burn TC, Pratta MA, Abbaszade I, Hollis JM, Liu R, Rosenfeld SA, Copeland RA, Decicco CP, Wynn R, Rockwell A, Yang F, Duke JL, Solomon K, George H, Bruckner R, Nagase H, Itoh Y, Ellis DM, Ross H, Wiswall BH, Murphy K, Hillman MC Jr, Hollis GF, Newton RC, Magolda RL, Trzaskos JM, Arner EC (1999) Purification and cloning of aggrecanase-1: a member of the ADAMTS family of proteins. Science 284:1664-1666

Turk BE, Huang LL, Piro ET, Cantley LC (2001) Determination of protease cleavage site motifs using mixture-based oriented peptide libraries. Nat Biotechnol 19:661-667

Ujita M, Shinomura T, Ito K, Kitagawa Y, Kimata K (1994) Expression and binding activity of the carboxyl-terminal portion of the core protein of PG-M, a large chondroitin sulfate proteoglycan. J Biol Chem 269:27603-27609

Watanabe H, Yamada Y (1999) Mice lacking link protein develop dwarfism and craniofacial abnormalities. Nat Genet 21:225-229

Watanabe H, Kimata K, Line S, Strong D, Gao LY, Kozak CA, Yamada Y (1994) Mouse cartilage matrix deficiency (cmd) caused by a $7 \mathrm{bp}$ deletion in the aggrecan gene. Nat Genet 7:154-157

Weber P, Bartsch U, Rasband MN, Czaniera R, Lang Y, Bluethmann H, Margolis RU, Levinson SR, Shrager P, Montag D, Schachner M (1999) Mice deficient for tenascin-R display alterations of the extracellular matrix and decreased axonal conduction velocities in the CNS. J Neurosci 19:4245-4262

Weigel PH, Hascall VC, Tammi M (1997) Hyaluronan synthases. J Biol Chem 272:13997-14000
Westling J, Gottschall PE, Thompson VP, Cockburn A, Perides G, Zimmermann DR, Sandy JD (2004) ADAMTS4 (aggrecanase-1) cleaves human brain versican V2 at Glu405-Gln406 to generate glial hyaluronate binding protein. Biochem J 377:787-795

Xiao ZC, Bartsch U, Margolis RK, Rougon G, Montag D, Schachner $M$ (1997) Isolation of a tenascin-R binding protein from mouse brain membranes - a phosphacan-related chondroitin sulfate proteoglycan. J Biol Chem 272:32092-32101

Yamada H, Watanabe K, Shimonaka M, Yamasaki M, Yamaguchi Y (1995) cDNA cloning and the identification of an aggrecanaselike cleavage site in rat brevican. Biochem Biophys Res Commun 216:957-963

Yamada H, Fredette B, Shitara K, Hagihara K, Miura R, Ranscht B, Stallcup WB, Yamaguchi Y (1997a) The brain chondroitin sulfate proteoglycan brevican associates with astrocytes ensheathing cerebellar glomeruli and inhibits neurite outgrowth from granule neurons. J Neurosci 17:7784-7795

Yamada K, Yamada T, Sasaki T, Rahemtulla F, Takagi M (1997b) Light and electron microscopical immunohistochemical localization of large proteoglycans in human tooth germs at the bell stage. Histochem J 29:167-175

Yamagata M, Sanes JR (2005) Versican in the developing brain: lamina-specific expression in interneuronal subsets and role in presynaptic maturation. J Neurosci 25:8457-8467

Yamagata M, Shinomura T, Kimata K (1993) Tissue variation of two large chondroitin sulfate proteoglycans (PG-M/versican and PGH/aggrecan) in chick embryos. Anat Embryol Berl 187:433-444

Yamaguchi Y (1996) Brevican-a major proteoglycan in adult brain. Perspect Dev Neurobiol 3:307-317

Yamaguchi Y (2000) Lecticans: organizers of the brain extracellular matrix. Cell Mol Life Sci 57:276-289

Yuan W, Matthews RT, Sandy JD, Gottschall PE (2002) Association between protease-specific proteolytic cleavage of brevican and synaptic loss in the dentate gyrus of kainate-treated rats. Neuroscience 114:1091-1101

Zako M, Iwaki M, Yoneda M, Miyaishi O, Zhao J, Suzuki Y, Takeuchi M, Miyake G, Ikagawa H, Kimata K (2002) Molecular cloning and characterization of chick sialoprotein associated with cones and rods, a developmentally regulated glycoprotein of interphotoreceptor matrix. J Biol Chem 277:25592-25600

Zako M, Shinomura T, Ujita M, Ito K, Kimata K (1995) Expression of PG-M (V3), an alternative splice form of PG-M without a chondroitin sulfate attachment region in mouse and human tissues. J Biol Chem 270:3914-3918

Zeng W, Corcoran C, Collins-Racie LA, Lavallie ER, Morris EA, Flannery CR (2006) Glycosaminoglycan-binding properties and aggrecanase activities of truncated ADAMTSs: comparative analyses with ADAMTS-5, -9, -16 and -18. Biochim Biophys Acta 1760:517-524

Zheng B, Lee JK, Xie F (2006) Genetic mouse models for studying inhibitors of spinal axon regeneration. Trends Neurosci 29:640646

Zhou XH, Brakebusch C, Matthies H, Oohashi T, Hirsch E, Moser M, Krug M, Seidenbecher CI, Boeckers TM, Rauch U, Buettner R, Gundelfinger ED, Fassler R (2001) Neurocan is dispensable for brain development. Mol Cell Biol 21:5970-5978

Zimmermann DR, Ruoslahti E (1989) Multiple domains of the large fibroblast proteoglycan, versican. EMBO J 8:2975-2981

Zimmermann DR, Dours-Zimmermann MT, Schubert M, BrucknerTuderman L (1994) Versican is expressed in the proliferating zone in the epidermis and in association with the elastic network of the dermis. J Cell Biol 124:817-825

Zurn AD, Bandtlow CE (2006) Regeneration failure in the CNs: cellular and molecular mechanisms. Adv Exp Med Biol 557:54-76 